\title{
The Role of microRNAs in the Pathogenesis of Herpesvirus Infection
}

\author{
Diogo Piedade and José Miguel Azevedo-Pereira *
}

Host-Pathogen Interaction Unit, iMed.ULisboa, Faculdade de Farmácia, Universidade de Lisboa, 1649-003 Lisboa, Portugal; diogo.piedade.92@gmail.com

* Correspondence: miguel.pereira@ff.ul.pt; Tel.: +351-21-794-6400

Academic Editor: Alexander Ploss

Received: 8 March 2016; Accepted: 30 May 2016; Published: 2 June 2016

\begin{abstract}
MicroRNAs (miRNAs) are small non-coding RNAs important in gene regulation. They are able to regulate mRNA translation through base-pair complementarity. Cellular miRNAs have been involved in the regulation of nearly all cellular pathways, and their deregulation has been associated with several diseases such as cancer. Given the importance of microRNAs to cell homeostasis, it is no surprise that viruses have evolved to take advantage of this cellular pathway. Viruses have been reported to be able to encode and express functional viral microRNAs that target both viral and cellular transcripts. Moreover, viral inhibition of key proteins from the microRNA pathway and important changes in cellular microRNA pool have been reported upon viral infection. In addition, viruses have developed multiple mechanisms to avoid being targeted by cellular microRNAs. This complex interaction between host and viruses to control the microRNA pathway usually favors viral infection and persistence by either reducing immune detection, avoiding apoptosis, promoting cell growth, or promoting lytic or latent infection. One of the best examples of this virus-host-microRNA interplay emanates from members of the Herperviridae family, namely the herpes simplex virus type 1 and type 2 (HSV-1 and HSV-2), human cytomegalovirus (HCMV), human herpesvirus 8 (HHV-8), and the Epstein-Barr virus (EBV). In this review, we will focus on the general functions of microRNAs and the interactions between herpesviruses, human hosts, and microRNAs and will delve into the related mechanisms that contribute to infection and pathogenesis.
\end{abstract}

Keywords: microRNAs; herpesvirus; pathogenesis; latency; oncogenesis; immune evasion

\section{Introduction}

MicroRNAs (miRNAs) are small, approximately 22-nucleoide-long, non-coding RNAs that regulate gene expression [1-4]. They were discovered in 1993 in studies into the development of Caenorhabditis elegans $[5,6]$. Gene expression control exerted by miRNAs is post-transcriptional as miRNAs regulate mRNA translation and stability in the cytoplasm [7-9]. There are over 1000 miRNAs encoded in the human genome, and they are predicted to regulate over $60 \%$ of our genes $[10,11]$. Hence, miRNAs seem to participate in virtually every cellular process, and changes in their expression are present in human pathologies [12-15].

Interactions between viruses and the RNA interference (RNAi) pathway, which includes miRNA and small interfering RNA (siRNA) pathways, were first described during viral infection of plants and afterwards tested in Drosophila systems $[16,17]$. Despite evidence in plants and insects, it was thought that this pathway was not antiviral in mammalian cells due to interferon system activation by viral dsRNA [18]. It was only with the discovery that siRNAs did not induce interferon machinery [19] and that the interplay between viruses and RNAi machinery was considered.

To date, several types of mutual interference between a virus and the host cell's miRNA machinery have been described. Viruses can (i) avoid cellular miRNAs targeting viral mRNAs [20]; (ii) block or 
impair the miRNA pathway by interacting with some key proteins [21,22]; (iii) synthesize their own miRNA to generate a more favorable cellular environment or to regulate their own mRNAs [23,24]; or (iv) make use of cellular miRNAs to their favor [25]. On the other hand, cells are also able to target viral mRNAs with endogenous miRNAs [26-28]. This interplay between the host-cell's miRNAs and viruses raises a complex equilibrium where, most of the time, viruses have the advantage and are able to escape the immune response and make use of cellular miRNAs in order to complete their replication cycle. However, several degrees of uncertainty are present; the experimental challenges raised by miRNA target prediction and functional validation is one of the most important issues that should be highlighted, motivating the development of methods to effectively assess miRNA functions.

Herpesviridae is a family of large nuclear DNA viruses (herpesviruses). These viruses are able to establish lifelong infection in their host due to interchange between lytic (productive) and latent (non-productive) infection [29,30]. There are eight human herpesvirus that can be subdivided in three subfamilies: (i) Alphaherpesvirinae; (ii) Betaherpesvirinae; and (iii) Gammaherpesvirinae [30]. Herpesvirus infection is associated with a large array of clinical manifestations spanning from skin/mucosal lesions to several malignancies. The focus of this review will cover all three subfamilies but will mainly discuss herpesviruses that are known to encode miRNAs.

Among all viral miRNAs already identified, the majority is encoded and expressed by herpesviruses [24,31]. Human herpesvirus confirmed to encode miRNAs are: the herpes simplex virus type 1 and type 2 (HSV-1 and HSV-2) both belonging to the Alphaherpesvirinae subfamily [32], human cytomegalovirus (HCMV) from the Betaherpesvirinae subfamily [33], and, finally, the Epstein-Barr virus (EBV) and human herpesvirus 8 (HHV-8), also known as Kaposi's sarcoma-associated herpesvirus (KSHV), both from Gammaherpesvirinae subfamily [34,35].

Herpesviruses' miRNAs are able to target both cellular and viral mRNAs. Host miRNA-targeted mRNAs are mostly related to cell proliferation regulation, apoptosis, and host immunity. Viral mRNA targets present various functions, and viral miRNAs seem to have a role in evading host immunity and regulating lytic and latent infection [30,36-39].

\section{Overview of miRNA Biogenesis}

miRNA biogenesis begins in the nucleus with the transcription of miRNA genes by RNA polymerase II [40]. miRNA genes are often found in clusters that are transcribed together in intergenic regions, and they have their own regulatory sequences in both sense and antisense orientations [41]. These transcripts, known as primary-miRNAs (pri-miRNAs), contain a $5^{\prime}$-end cap and a poly-A tail sequence.

Pri-miRNAs are processed to functional miRNAs in two steps catalysed by two enzymes of the RNase III family, Drosha and Dicer. The first step is mediated by the Drosha and DiGeorge syndrome critical region gene-8 (DGCR8) complex [42] and occurs in the nucleus. During this step, pri-miRNAs are processed to precursor miRNAs (pre-miRNAs) that are exported from the nucleus by Exportin-5 [43-45]. The second step takes place in the cytoplasm where pre-miRNAs are further processed by Dicer [46,47]. This final processing step produces a 21- to 25-nucleotide mature dsRNA that is ready to be loaded into a RNA-induced silencing complex (RISC) [48], forming the miRNA-induced RISC (miRISC) where miRNA-mRNA binding occurs (further reviewed in [49]).

miRNAs recognize and interact with the corresponding mRNA by base-pair complementarity. Generally, animal cells' miRNAs pair imperfectly with target mRNAs in the $3^{\prime}$ untranslated region ( $3^{\prime}$ UTR). In order to effectively suppress their target mRNAs, miRNAs must be perfect and contiguously complementary in their nucleotides 2-8 at the $5^{\prime}$ end; this region is called the 'seed' region and it nucleates the interaction $[50,51]$. However, additional $3^{\prime}$ pairing increases the miRNA-induced repression [51], suggesting that multiple miRNAs are needed to regulate target expression if miRNA complementary is only based in the $5^{\prime}$ seed region. The need for a synergistic binding of distinct miRNAs may constitute an additional mechanism of miRNA-mediated inhibition of translation in animal cells [50]. miRNAs can repress mRNA in two distinct ways: they could inhibit translation, 
or they can destabilize mRNAs. The most recent studies suggest that these two mechanisms occur in sequence [52-56], indicating that destabilization of target mRNA is the last and predominant step in mRNA repression [52,57].

\section{Alphaherpesvirus (HSV-1 and HSV-2) and microRNAs}

\subsection{Targeting Viral Transcripts to Maintain Latency}

Alphaherpesviruses, especially both serotypes of human simplex virus, type 1 and type 2 (HSV-1 and HSV-2), infect humans by contact of oral or genital mucosa with viral particles. From the mucosa, the virus migrates and establishes a latent infection in sensory or autonomic neurons near the primary site of infection [32,58]. During latent infection by HSV, only a non-coding viral RNA known as latency-associated transcript (LAT) is expressed [59]. Although not essential for latency establishment, maintenance, or reactivation [60], LAT plays an important role in these processes probably by interfering with other viral transcripts due to LAT-encoded miRNAs [61-65].

HSV-1 encodes 18 stem-loops that result in 27 mature miRNA sequences [61,63,64,66-69], while HSV-2 also encodes for 18 stem-loops but only produce 24 mature miRNAs [62,65,66] (Figure 1). The first report of a HSV-1 miRNA was in 2006 [61]; since then, several studies have attempted to unravel the functions of HSV-1 miRNAs $[62,63,67,70,71]$. Despite these efforts, the functions of the majority of HSV-1 miRNA functions remain unknown. Even so, the functions that have already been revealed point to a relevant role of HSV-1 miRNAs in the regulation of latency. One good example is the targeting of the infected cell polypeptide 4 (ICP4) protein by hsv1-miR-H6 [70]. ICP4 protein is an immediate early gene of HSV-1 that upregulates early and late genes of HSV-1 and downregulates LAT, driving the virus towards lytic infection $[62,67,70]$. Therefore, hsv1-miR-H6 seems to play an important role in latency maintenance of HSV-1 [70]. Another HSV-1 miRNA that potentially regulates latency is hsv1-miR-H2. This viral miRNA targets ICP0 protein, other immediate early gene that acts as an activator of immediate early, early, and late genes of HSV-1 [62,67]. ICP0 has a major role in lytic infection and reactivation, and its expression promotes the entry of HSV-1 in replication cycle $[67,72]$. Another viral protein targeted by HSV-1 miRNAs is ICP34.5, an important lytic neurovirulence factor. ICP34.5 is targeted by two viral miRNAs, hsv1-miR-H3 and hsv1-miR-H4, encoded in an antisense orientation to the viral factor $[62,63,67]$. Altogether, these results indicate that hsv1-miR-H6, hsv1-miR-H2, hsv1-miR-H3, and hsv1-miR-H4 seem to play a role in the establishment and maintenance of latency while evading host immune surveillance.

Despite the fact that most identified targets of HSV-1 miRNAs are virus-encoded, hsv1-miR-H27 targets cellular transcriptional repressor Kelch-like 24 (KLHL24), which inhibits transcriptional efficiency of viral immediate early and early genes. Thus, opposite to other viral miRNAs, hsv1-miR-H27 seems to have an important role in immune evasion, viral replication, and proliferation [68]. Interestingly, HSV-2 and HSV-1 share a great homology between mRNA sequences [32,66]. Unsurprisingly, HSV-2 miRNAs sharing homology with HSV-1 miRNAs have similar functions, as it is the case of hsv2-miR-H2 and hsv2-miR-H3/4, which target ICP0 and ICP34.5, respectively. Therefore, HSV-2 miRNAs contribute to latency and immune evasion in an almost identical way to HSV-1 miRNAs [62,65,66,71]. 


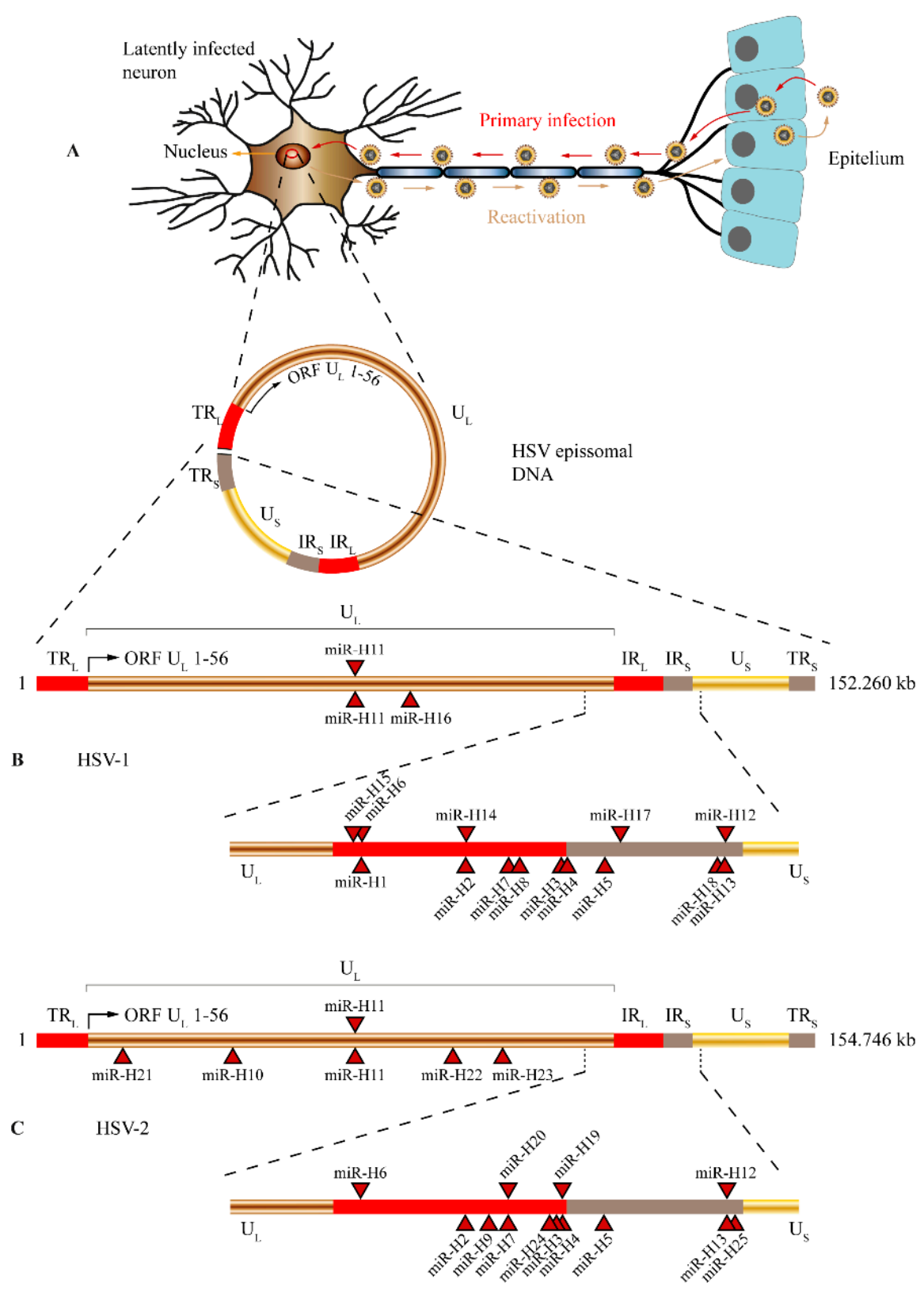

Figure 1. Viral genomic DNA structure and location of microRNAs (miRNAs) encoded by herpes simplex virus type 1 and type 2 (HSV-1 and HSV-2). (A) Episomal DNA in a latently infected neuron. After primary infection, HSV-1 or HSV-2 virions migrate from oral or genital mucosa to a sensitive neuron that enervates those tissues establishing a latent infection. The migration through neuronal dendrites occurs by a retrograde microtubule-associated transport, allowing HSV to reach nerve cell body. As a response to several exogenous or endogenous stimuli, the latent virus is reactivated and viral particles are anterograde transported to the mucosa where they infect epithelial cells allowing viral transmission. During latency, the HSV genome is maintained as a circular episome (represented as a red circle inside the nucleus). The structure and prototypic arrangement of the HSV episome is presented. $\mathrm{U}_{\mathrm{L}}$ (copper) and $\mathrm{U}_{\mathrm{S}}$ (gold) represent the long and short components of the viral genome. $\mathrm{TR}_{\mathrm{L}}$ and $I R_{\mathrm{L}}$ (in red) represent the repeat sequences flanking $\mathrm{U}_{\mathrm{L}}$ and $T R_{\mathrm{S}}$, and $I R_{S}$ (in light brown) represent the repeat sequences flanking $U_{S}$. Genomic location of miRNAs encoded by HSV-1 (B) and HSV-2 (C). A linear representation of both HSV-1 and HSV-2 genomes are shown, and the locations of miRNA precursors encoded by each virus are denoted by red triangles. The regions of the internal repeat sequences $\left(\mathrm{IR}_{\mathrm{L}}\right.$ and $\left.\mathrm{IR}_{\mathrm{S}}\right)$ are expanded in the bottom of each genome. miRNAs shown below the line representing viral double-strand DNA are transcribed in an antisense direction (from left to right), while those shown above the line are transcribed in the opposite orientation. 


\section{2. miRNAs Patterns of Accumulation in Alphaherpesvirus Support Viral miRNAs Predicted Functions}

Given the apparent role of HSV miRNAs in the establishment of latency, the pattern of accumulation of HSV-1 miRNAs in infected cells was evaluated in order to confirm differential expression of miRNAs in lytic and latent infection [58,67]. Not surprisingly, patterns of viral miRNA expression support the proposed functions for these viral transcripts. All latency-associated viral miRNAs, namely, hsv1-miR-H6, hsv1-miR-H2, hsv1-miR-H3, and hsv1-miR-H4, were upregulated in cells harvested from latently infected murine ganglia [58]. Interestingly, hsv1-miR-H5 and hsv1-miR-H7 also shown a similar pattern of expression, suggesting a potential role for these miRNAs in the latency of HSV-1 [58]. Moreover, several other viral miRNAs levels were significantly increased upon HSV-1 reactivation. Among these is hsv1-miR-H27, supporting its role in efficient replication and proliferation [58]. Besides hsv1-miR-H27, hsv1-miR-H15, hsv1-miR-H17, hsv1-miR-H18, and hsv1-miR-H26 also had a significant increase in their levels, suggesting a potential role in HSV-1 reactivation [58].

\subsection{Cellular miRNAs Are Involved in Infection and Latency of Alphaherpesvirus}

Another aspect worth mentioning regarding HSV-1 and miRNAs are the cellular miRNAs that interfere with viral replication. In fact, cellular miRNAs are known to be engaged in several antiviral functions [26], and HSV-1 infection is no exception. Cellular miRNA miR-101 targets the $3^{\prime}$ untranslated region of mitochondrial ATP synthase subunit beta (ATP5B), a cellular protein that plays a role in viral infection, reducing HSV-1 replication [73]. Therefore, this miR-101/ ATP5B axis acts as a cellular defence that avoids lytic replication of HSV-1 and may contribute to latency [73]. Interestingly, miR-23a was found to facilitate HSV-1 replication by targeting interferon regulatory factor 1 (IRF1) and inhibiting the interferon pathway, an antiviral innate immune pathway [74]. This complex interaction is not yet fully understood, and the mechanisms by which HSV-1 induces miR-23a expression are not clear [74]. Another cellular miRNA altered by HSV-1 infection is miR-146a [75]. HSV-1 induces the pro-inflammatory miR-146a. This cellular miRNA is known to target complement factor $\mathrm{H}$ and to induce key elements of the arachidonic acid cascade. Thus, this mechanism provides an HSV-1 way to evade the complement while contributing to an Alzheimer-type neuropathological change [75].

In conclusion, alphaherpesviruses evolved in a way that allows them to establish lifelong latency in host neurons. Viral miRNAs and the interplay between cellular miRNAs and HSV-1 and HSV-2 seem to play an important role in the events related to latency, such as establishment, maintenance, and reactivation of the virus. In addition, miRNAs have shown to be linked with pathological events related to HSV infection. Therefore, HSV miRNAs may constitute a new and different approach to antiviral therapy.

\section{Human Cytomegalovirus microRNAs}

Human cytomegalovirus (HCMV) belongs to the Betaherpesvirinae subfamily and characteristically establishes latent infection upon resolution of acute infection [76]. HCMV infection can cause increased morbidity and mortality in immunosuppressed patients such as transplant recipients and human immunodeficiency virus (HIV)-infected patients [76]. Furthermore, HCMV primary infection during pregnancy is also associated with congenital infection, leading to severe birth defects and neonatal pathologies. The HCMV miRNAs can target both viral and host genes, playing a key role in latency and replication of HCMV [77]. There is contradictory evidence regarding the amount of miRNAs expressed by HCMV. While miRBase [11] data point to 15 stem-loop precursors and 26 mature miRNA sequences, the latest reports only account for 21 mature miRNA sequences originating from 14 precursors [77] (Figure 2). Contrary to other herpesvirus subfamilies, HCMV miRNAs are not clustered in regions associated with latent transcripts; instead, HCMV miRNAs are dispersed throughout the viral genome as single miRNAs or small clusters [78-81] (Figure 2). 


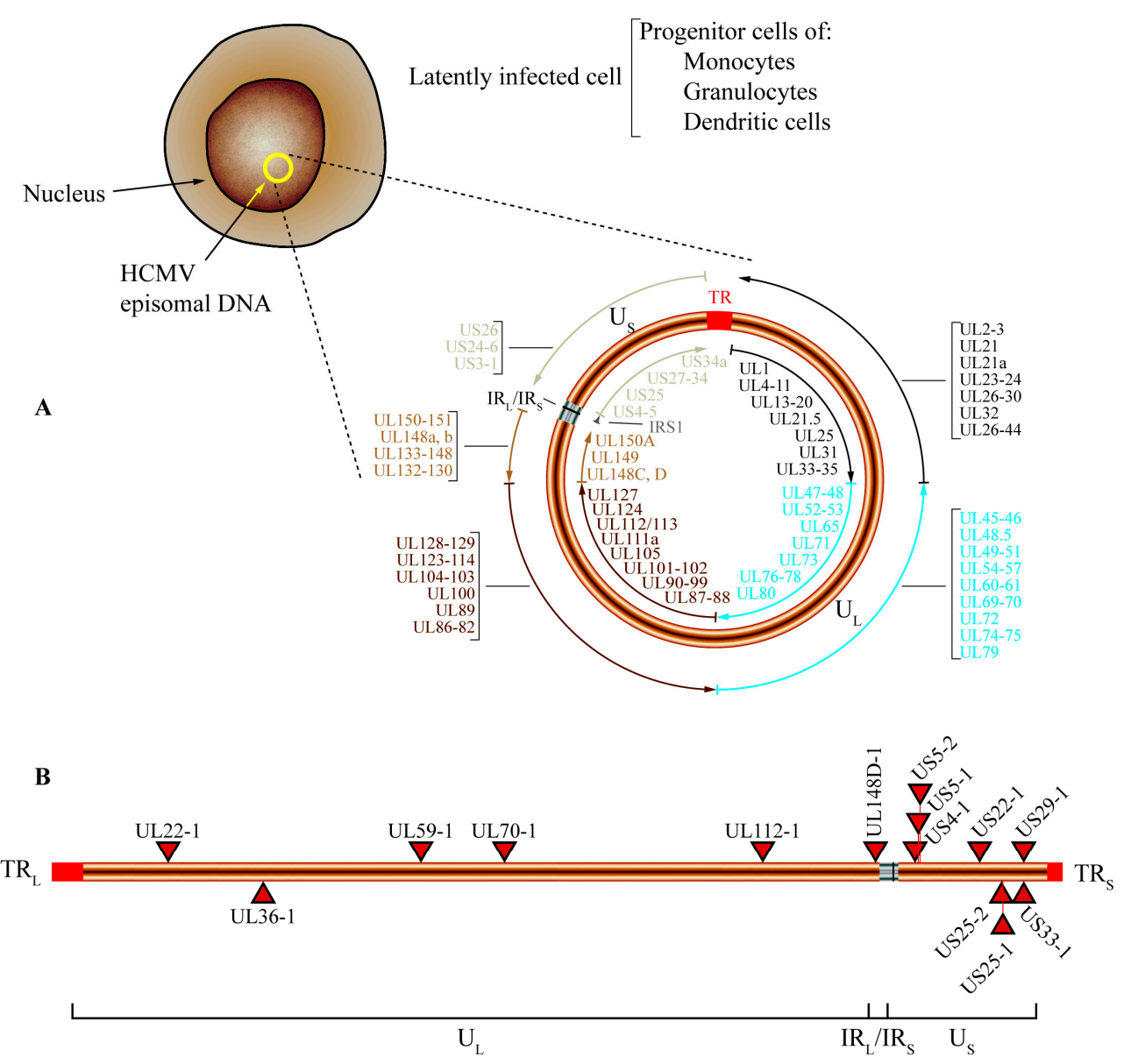

Figure 2. Genome organization and location of miRNA encoded by human cytomegalovirus (HCMV). (A) After primary infection HCMV establishes a latent infection in progenitor cells of monocytes, dendritic cells, and granulocytes. During latency, the HCMV genome is maintained as a circular episome (represented as a yellow circle inside the nucleus). The general structure of episomal DNA is presented, and the relative positions of the open reading frames (ORFs) are shown. $U_{L}$ and $U_{S}$ represent the long and short components of the viral genome, TR (red) denotes the terminal repeats, and $\mathrm{IR}_{\mathrm{L}} / \mathrm{IR}_{\mathrm{S}}$ (grey) represents the internal repeats of the long and short components of the HCMV genome. The outer circular arrows refer to the ORFs that are transcribed in antisense orientation, while the inner circular arrows refer to those that are transcribed in the opposite orientation. To facilitate the representation of the different ORFs and their relative location, the outer and inner circular arrows are presented in different colors; the black circular arrows represent those ORFs encoded between 12 and $58 \mathrm{~kb}$ of the HCMV genome, the blue circular arrows represent ORFs encoded between 59 and $118 \mathrm{~kb}$, the dark brown circular arrows denote the ORFs encoded between 119 and $177 \mathrm{~kb}$, the light brown circular arrows refer to the ORFs located between $178 \mathrm{~kb}$ and the IRL/IRS region, and finally the light grey circular arrows represent the ORFs that are encoded after the IRL/IRS region; (B) Genomic location of miRNAs encoded by HCMV. A linear representation of the HCMV genome is shown and the locations of miRNA precursors are denoted by red triangles. miRNAs shown below the line representing viral double-strand DNA are transcribed in antisense direction (from left to right), while those shown above are transcribed in the opposite orientation.

\subsection{HCMV miRNAs Target Cellular Genes to Evade Immune System and Control Cell Cycle as Well as Vesicle Trafficking}

HCMV miRNAs were predicted to target several cellular pathways - in particular, those related with immune response, cell cycle control, and vesicle trafficking [33,77]. Regarding immune evasion, 
HCMV miRNAs were confirmed to target multiple pathways, ranging from cell recognition and proliferation to cytokine secretion. For example, the viral miRNA hcmv-miR-UL112 targets the major histocompatibility complex class-I related chain B (MICB) reducing natural-killer (NK) group 2, member D (NKG2D) recognition, helping the evasion of HCMV from NK cells [82]. Interestingly, the hcmv-miR-UL112 binding site has been shown to overlap the one from cellular miRNA hsa-miR-373, preventing site mutation by the host [83]. Additionally, this viral miRNA was found to act synergistically with another cellular miRNA, hsa-miR-376a. Both cellular and viral miRNA were able to decrease MICB levels and NK-mediated cell killing, suggesting that HCMV may have evolved in a way that allows cooperation with host miRNAs and the targeting of highly conserved sequences in 3'UTR of host mRNA [83]. Moreover, hcmv-miR-UL112-1 was reported to target interleukin-32 which is critical for innate and adaptive immune response [84]. Another viral miRNA that targets cellular mRNA related to immune evasion is hcmv-miR-US25-2-3p, which is known to target tissue inhibitors of metalloprotease 3 (TIMP3), resulting in an increased shedding of major histocompatibility complex class-I related chain A (MICA) and, again, decreasing NK cells recognition [85]. Additionally, HCMV miRNA UL148D (hcmv-miR-UL148D) also contributes to immune evasion by targeting the $3^{\prime}$ UTR of the chemokine (C-C Motif) ligand 5 (CCL5) gene [86]. The CCL5 protein is a chemokine that induces NK cells proliferation and activation [87]; thus, hcmv-miR-UL148D, together with hcmv-miR-UL112 and hcmv-miR-UL112-1, contributes to HCMV NK evasion. Another mechanism of immune evasion was provided by a recent finding suggesting that hcmv-miR-UL112-3p targets toll-like receptors 2 (TLR2), inhibiting NFKB signaling and avoiding the associated inflammatory response [88]. Finally, the viral miRNA, hcmv-miR-US4-1, was confirmed to contribute to immune evasion by affecting antigen presentation by the major histocompatibility complex, class I (MHC-I) to cytotoxic T lymphocytes. The viral miRNA accomplishes this by targeting the endoplasmic reticulum aminopeptidase 1 (ERAP1) gene, preventing antigen peptide production [89]. Altogether, these viral miRNAs represent a potent viral mechanism of immune evasion by HCMV, acting together with other viral factors [90].

Another important group of cellular genes targeted by HCMV miRNAs are those associated with cell cycle control. By interfering with cell cycle control, HCMV is able to regulate the latent and lytic cycles, thus contributing to lifelong infection of the host. One important viral miRNA interfering with cell cycle is hcmv-miR-US25-1. This viral miRNA was found to target 20 different cellular transcripts. Among its targets were cyclin E2 (CCNE2), the collagenase stimulatory factor (CD147), the BRCA1/BRCA2-containing complex, subunit 3 (BRCC3), the EP300 interacting inhibitor of differentiation 1 (EID1), microtubule-associated proteins, the RP/EB family, member 2 (MAPRE2), and histone proteins (H3F3B), all with known functions in cell cycle control [91,92]. Interestingly, several hcmv-miR-US25-1 targets contained seed sequences in the 5'UTR of mRNA instead of the canonical 3'UTR [4], but the functional meaning of this finding has not yet been revealed [92]. Another cellular factor targeted by HCMV miRNAs is the eukaryotic initiation factor 4A1 (eIF4A1), an RNA helicase essential for translation initiation. Expression levels of eIF4A1 decreased due to hcmv-miR-US25-2-3p targeting [93]. This mechanism of translation inhibition by HCMV stands as a possible way to promote latency and cell cycle control.

In addition to immune evasion and cell cycle control, HCMV also targeted a group of cellular transcripts involved in vesicle trafficking. For example, the ATPase, $\mathrm{H}^{+}$transporting, lysosomal $16 \mathrm{kDa}$, V0 subunit C pseudogene 1 (ATP6V0CP1) protein, which is required for acidification of endosomal compartments [94], is targeted by hcmv-miR-US25-1 viral miRNA. Similarly to other hcmv-miR-US25-1 targets, ATP6V0CP1 interference did not follow the canonical miRNA mechanism. Instead, viral miRNA seed sequences were located in the cellular gene open reading frame (ORF) [94], revealing yet another mechanism of interference for this particular viral miRNA. Interestingly, ATP6V0CP1 was found to be essential for viral replication, although the mechanism by which the absence of this cellular factor affects HCMV replication was not elucidated [94]. The fact that this cellular protein limits viral replication suggests that ATP6V0CP1 regulation may be important for viral control of replication and immune evasion during latency [94]. Three other viral miRNAs were found to target several genes 
of the secretory pathway. When collectively expressed, hcmv-miR-UL112-1, hcmv-miR-US5-1, and hcmv-miR-US5-2 targeted several proteins of this host pathway, including VAMP3 (vesicle-associated membrane protein 3), RAB5C (RAS-related protein 5C), RAB11A (RAS-related protein 11A), SNAP23 (synaptosomal-associated protein, $23 \mathrm{kDa}$ ), and CDC42 (cell division control protein 42) [95]. Interference of these host factors by HCMV-encoded miRNAs revealed another set of important functions inhibited by HCMV. This triple targeting affected the secretion of interleukin-6 (IL-6) and tumor necrosis factor $\alpha(\mathrm{TNF}-\alpha)$, the accumulation of transferrin in the endocytic recycling compartment (ERC), and the formation of the virion assembly compartment (VAC) [95]. Taken together, these effects of viral miRNAs were demonstrated to be essential for proper virion assembly [95].

\subsection{Viral miRNAs Target HCMV Transcripts}

Despite the fact that most identified HCMV miRNAs target cellular mRNAs, viral miRNAs can also interfere with HCMV transcripts. hcmv-miR-UL112-1 was identified to target a major immediate early trans-activator: the IE72. This immediate early viral transcript synthesis is important for HCMV DNA replication and expression of hcmv-miR112-1 reduced viral replication [91]. Interference with immediate early trans-activators is also observed with other herpesvirus-coded miRNAs, suggesting that targeting immediate early viral transcripts is an important mechanism to establish and maintain latency [96]. Interestingly, hcmv-miR-UL112-1 is encoded antisense to viral uracil DNA glycosylase (UL114), which increases both early and late viral transcripts synthesis [97]. Again, this miRNA poses as a viral factor that favors latency. Another viral gene targeted by viral miRNAs is the US7 protein. Although the functions of this viral gene remain elusive, the mechanism by which viral miRNAs target US7 3'UTR demonstrated a synergic repression by two viral miRNAs. In fact, hcmv-miRUS5-1 and hcmv-miRUS5-2 are encoded antisense to US7 3'UTR, and this finding stood as the first evidence of two HCMV miRNAs acting cooperatively [98]. Finally, hcmv-miR-UL36 was thought to target UL138, a determinant gene for latent infection [99], but the relevance of this miRNA remains uncertain, as it was not detected among latency-associated miRNAs [100].

\subsection{HCMV-Encoded miRNAs Are Expressed Differentially in Latent and Lytic Infection}

Similar to studies conducted with other viruses, HCMV miRNA expression changes between latent and lytic infection. In a recent report, eight viral miRNAs were found in latently infected cells, with hcmv-miR-UL112-3p and hcmv-miR-US22-5p being the two most abundant miRNAs during latency [100]. Interestingly, the majority of these miRNAs are encoded in the unique long (UL) region of the viral genome, suggesting the existence of regulatory mechanisms important for transition to the latent phase. In addition, a subset of viral miRNAs highly expressed in lytic infection (hcmv-miR-US25-2-5p, hcmv-miR-US29-5p, hcmv-miR-US25-1-5p, and hcmv-miR-US25-2-5p) presented a significant decay during the course of infection and establishment of latency [100]. Simultaneously, five miRNAs, including hcmv-miR-UL112-3p and hcmv-miR-US22-5p, were continuously expressed throughout infection by HCMV [100]. Interestingly, three miRNAs (i.e., hcmv-miR-US25-2-5p, hcmv-miR-US25-1-5p, and hcmv-miR-UL112-3p) show remarkable increase upon reactivation of lytic infection, demonstrating a distinct pattern of viral miRNA expression in lytic and latent infection [100]. Another intriguing finding was that hcmv-miR-US29 differentially expressed two mature miRNAs from two strands of pre-miRNA. Hence, during lytic infection, hcmv-miR-US29-5p was expressed and was undetectable during latent phase, while the opposite occurred with hcmv-miR-US29-3p [100]. This was the first demonstration of a viral mechanism that apparently is related to transition to latency.

\subsection{HCMV Transcripts Alter Cellular miRNA Expression}

HCMV infection causes profound changes in cellular miRNAs. Although the consequences of these changings are not completely understood, it is conceivable that HCMV alters cellular miRNA expression to favor viral replication. In a recent study, 49 cellular miRNAs were expressed differentially 
during HCMV infection [101]. Among those, 39 were upregulated and 10 were downregulated during latent infection. Unsurprisingly, several cellular miRNAs known to have antiviral functions were downregulated. Interestingly, besides its antiviral activity, downregulated hsa-miR-21 was also reported to have an important role in birth defects caused by congenital HCMV infection [102,103], contributing to the neuropathogenesis of HCMV infection of fetal central nervous system. On the other hand, hsa-miR-124, known to modulate monocyte and macrophage activation, was upregulated during HCMV latent infection. By inhibiting macrophage activation, hsa-miR-124 helps to create a cellular environment suitable for HCMV latent infection [101]. Moreover, cellular miRNAs deregulated by HCMV are thought to be linked to several important cellular functions such as cell proliferation, differentiation, and oncogenesis [104]. Together, these findings point to an interesting possibility to develop miRNA-based-therapies to reduce HCMV infection severity.

\subsection{Cellular miRNAs Target Viral Transcripts and Promote HCMV Latency}

Despite the described cellular miRNA deregulation by HCMV, one family of cellular miRNAs was discovered to target a viral immediate early transcript. UL112 is targeted by three of the five hsa-miR-200 miRNA family members. Hsa-miR-200b, hsa-miR-200c, and hsa-miR-429 target the 3'UTR of UL112 [105]. This immediate early transcript is one of two immediate early proteins that are known to start HCMV reactivation. Moreover, the hsa-miR-200 cluster also appears to be highly expressed in undifferentiated cells such as monocytes. Therefore, the presence of high levels of hsa-miR-200 miRNA in undifferentiated cells may promote latency by suppressing a key protein for HCMV gene expression, and the loss of this miRNA during differentiation may stand as an important switch that promotes lytic infection [105].

In conclusion, HCMV infection is a complex and dynamic process where cellular and viral factors interact, resulting in lifelong infection by the virus. miRNAs play an important role in HCMV infection, and their functions are still being deciphered. In the future, HCMV miRNAs may provide important information about HCMV infection, namely as diagnostic and prognostic markers of disease outcome [106]. Additionally, miRNAs can provide new therapeutic targets and novel approaches to HCMV treatment, similar to what happens with other viruses $[107,108]$.

\section{Gammaherpesviruses: Epstein-Barr Virus (EBV)-Encoded miRNAs}

The Epstein-Barr virus (EBV) is a herpesvirus that, similarly to other herpesviruses, establishes a lifelong latent infection. The most common manifestation of EBV primary infection is a clinical syndrome known as infectious mononucleosis, usually affecting adolescents and young adults. After initial infection, EBV genomic DNA is maintained as episomes in the nucleus of memory B-lymphocytes. [109]. Occasionally, the virus is reactivated and infects new cells (e.g., B-lymphocytes and epithelial cells), and infectious viral particles are shed mainly through saliva. Although EBV infection is usually benign, the most relevant aspect of EBV pathology is the ability to transform infected cells [109]. Given its transforming capacity, EBV has been associated with several cancer types. EBV is found in almost all cases of undifferentiated nasopharyngeal carcinoma (NPC), nasal NK/T-cell lymphoma (NKTL), and post-transplant lymphoma (PTLD), in sporadic and endemic Burkitt's lymphoma (BL) (15\%-30\% and 95\% of the cases, respectively), in some subsets of Hodgkin's disease (HD), in diffuse large B-cell lymphoma (DLBCL) (15\% of the cases), and in gastric carcinoma (GC) (10\% of the cases) [110]. Interestingly, EBV expresses different latency-associated genes depending on the infected cell, giving rise to four different patterns of gene expression known as latency types 0, I, II, and III [111]. Different latency types are found in different EBV-associated diseases [111]. Therefore, it is no surprise that EBV-encoded miRNAs are also differentially expressed depending on the infected cell and the host immune control [112]. EBV encodes 44 mature miRNAs from 25 precursors [113-119] (Figure 3). Viral miRNAs are distributed by three clusters: BHRF1-cluster, BART-cluster 1, and BART-cluster 2 [34]. 

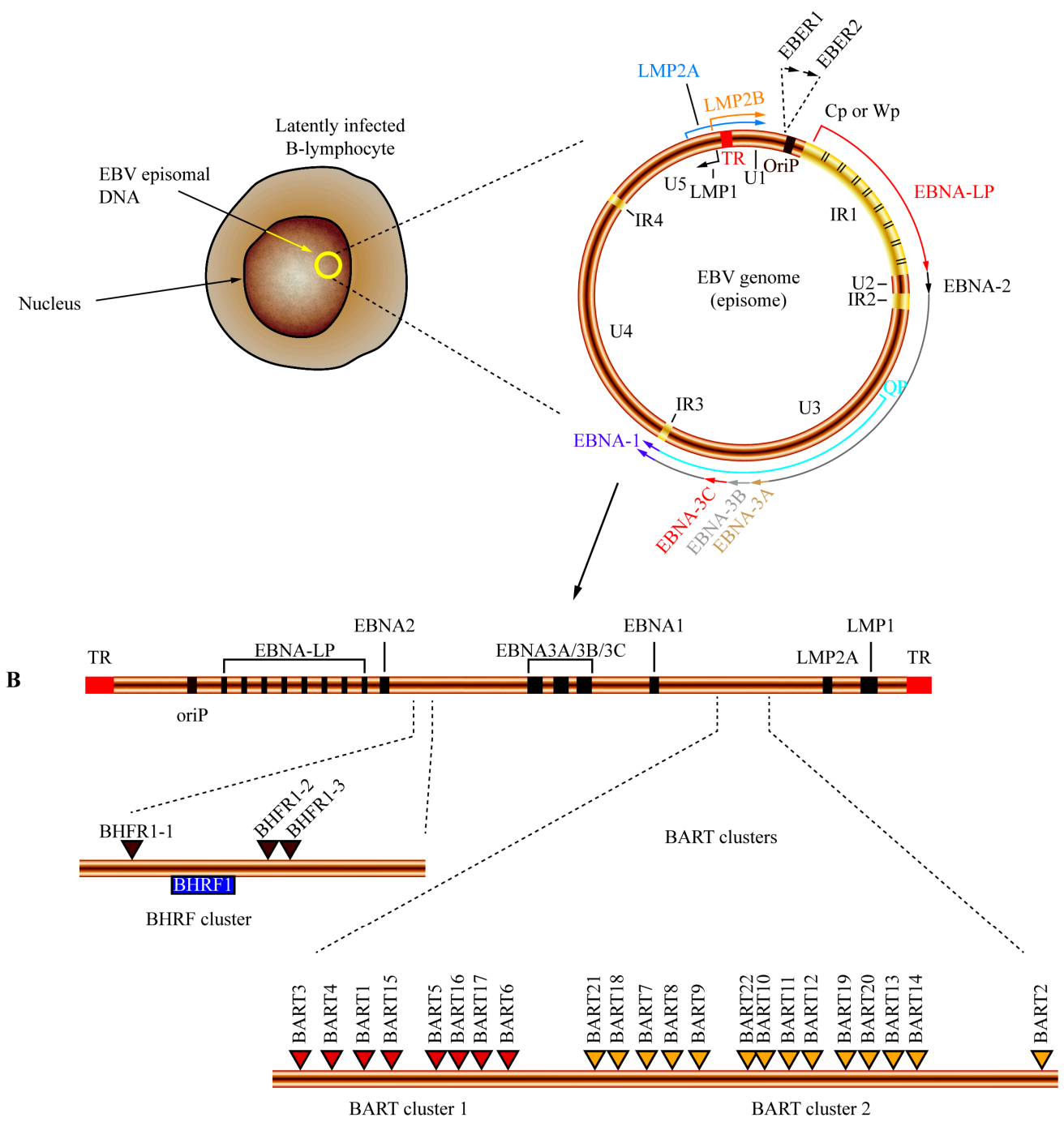

Figure 3. Genome organization and location of miRNAs encoded by the Epstein-Barr virus (EBV). (A) After primary infection, EBV establishes a latent infection in B-lymphocytes. During latency, the EBV genome is maintained as a circular episome (represented as a yellow circle inside the nucleus). The general structure of episomal DNA is presented, and the relative positions of the latency-associated genes on the viral episome are shown. The origin of plasmid replication (oriP) is shown in brown. The outer circle represents the coding regions of the latent proteins transcribed in antisense (LMP1, black arrow) and sense orientation (EBNA-LP, red; EBNA2, black; EBNA3A, light brown; EBNA3B, light grey; EBNA3C, red; EBNA1, purple; LMP2A, blue; LMP2B, orange). EBNA-LP is transcribed from variable numbers of repetitive exons (denoted by black lines inside the IR1 region). The highly transcribed non-polyadenylated RNAs EBER1 and EBER2 are represented in the top of the diagram. The outer long circular arrow represents the EBV transcript during the latency III program where all the EBNA genes are transcribed from $\mathrm{Cp}$ or $\mathrm{Wp}$ promoters. The inner blue arrow line represents the EBNA1 transcript originated from the Qp promoter during latency I and latency II programs. U1-U5 refers to largely unique DNA domains while IR1-IR4 represents internal repetitive DNA domains. TR (represented in red) denotes the terminal repeat of EBV DNA; (B) Genomic location of miRNAs encoded by EBV. A linear representation of EBV genome is shown and the positions of the main latent genes are represented by black boxes; a dark brown box denotes oriP position. The regions of the BHRF cluster and BART clusters 1 and 2 are expanded in the bottom of the diagram. The locations of miRNA precursors are denoted by brown (BHRF cluster), red (BART cluster 1) and yellow (BART cluster 2) triangles. 


\subsection{EBV-Encoded miRNAs Help Immune Evasion}

EBV miRNAs target both cellular and viral mRNAs to evade the immune system (Table 1). Viral miRNAs are able to supress viral antigens LMP1 and LMP2A, two latency-associated membrane proteins. Three different EBV miRNAs from BART-cluster 1 (ebv-miR-BART16, ebv-miR-BART17-5p, and evb-miR-BART1-5p) co-target LMP1 [120]. Despite being a known antigen, this modulation of LMP1 was not shown to be directly correlated with a decreased immune response. However, due to its role as pro-apoptotic protein, it is expected that the downmodulation of LMP1 provides an indirect mechanism of immune evasion $[37,120]$. Concerning the other latency-associated membrane protein, LMP2A, a similar mechanism for immune evasion is proposed, pointing to a modulation of this viral protein resulting in immune surveillance escape [117]. This was shown due to high sequence complementarity between LMP2 and ebv-miR-BART22. Furthermore, high levels of the viral miRNA correlated with low levels of this viral transcript [117], providing strong evidence that this viral miRNA targets LMP2A. As observed with many other miRNAs, it should be emphasized that some of these functions, although suggesting potential mechanisms of immune evasion, are in general not completely demonstrated.

Table 1. MicroRNAs (EBV- or cell-encoded) with potential role in EBV infection and pathogenesis.

\begin{tabular}{|c|c|c|c|c|}
\hline \multicolumn{2}{|c|}{ miRNA } & \multirow{2}{*}{$\frac{\text { Target }^{*}}{\text { CXCL11 (c) }}$} & \multirow{2}{*}{$\frac{\text { Predicted Role }}{\text { Immune evasion }}$} & \multirow{2}{*}{$\frac{\text { References }}{[121]}$} \\
\hline \multirow{21}{*}{$\begin{array}{l}\text { EBV-encoded } \\
\text { (ebv-miR-) }\end{array}$} & BHRF1-3 & & & \\
\hline & BART1 & $\mathrm{BIM}(\mathrm{c})$ & Inhibits apoptosis & [122] \\
\hline & BART1-3p & Caspase-3 (c) & Inhibits apoptosis & [123] \\
\hline & BART1-5p & LMP1 (v) & Immune evasion & [120] \\
\hline & BART2-5p & $\operatorname{MICB}(\mathrm{c})$ & Immune evasion & [124] \\
\hline & BART3 & $\mathrm{BIM}(\mathrm{c})$ & Inhibits apoptosis & [122] \\
\hline & BART3-5p & DICE1 (c) & Cell transformation and proliferation & [125] \\
\hline & BART5-5p & PUMA (c) & Inhibits apoptosis & [126] \\
\hline & BART6-5p & Dicer $(\mathrm{c})$ & Modulates biogenesis of microRNAs & {$[127,128]$} \\
\hline & BART7 & $\mathrm{APC}(\mathrm{c})$ & Cell transformation and proliferation & [129] \\
\hline & BART9 & $\mathrm{BIM}(\mathrm{c})$ & Inhibits apoptosis & [122] \\
\hline & BART11 & $\mathrm{BIM}(\mathrm{c})$ & Inhibits apoptosis & [122] \\
\hline & BART12 & BIM (c) & Inhibits apoptosis & [122] \\
\hline & BART15 & NLRP3 (c) & Immune evasion & [130] \\
\hline & & LMP1 (v) & Immune evasion & [130] \\
\hline & BART16 & TOMM22 (c) & Inhibits apoptosis & [122] \\
\hline & & Caspase-3 (c) & Inhibits apoptosis & [123] \\
\hline & BART17-5p & LMP1 (v) & Immune evasion & [120] \\
\hline & & WIF1 (c) & Cell transformation and proliferation & [129] \\
\hline & ВАК119-3p & $\mathrm{APC}(\mathrm{c})$ & Cell transformation and proliferation & [129] \\
\hline & BART20-5p & $\mathrm{BAD}(\mathrm{c})$ & Inhibits apoptosis & [131] \\
\hline \multirow{3}{*}{$\begin{array}{l}\text { Cell-encoded } \\
\text { (hsa-miR-) }\end{array}$} & let-7a & Dicer $(c)$ & Modulates biogenesis of microRNAs & [132] \\
\hline & $200 b$ & ZEB1, ZEB2 (c) & Modulates latent/lytic infection & {$[133,134]$} \\
\hline & 429 & ZEB1, ZEB2 (c) & Modulates latent/lytic infection & {$[133,134]$} \\
\hline
\end{tabular}

* Detailed information on potential targets is mentioned in the text. Abbreviations used: APC-adenomatous polyposis coli; BAD-BCL2-associated agonist of cell death; BIM-BCL2 interacting mediator of cell death; CXCL11-C-X-C motif chemokine 11; DICE1—Deleted in cancer 1; LMP-Latent membrane protein; MICB - major histocompatibility complex class-I related chain B; NLRP3-NLR family, pyrin domain containing 3; PUMA - p53-upregulated modulator of apoptosis; TOMM22-translocase of outer mitochondrial membrane 22 homolog (yeast); ZEB1 / ZEB2-Zinc finger E-box-binding homeobox (1 or 2); (c) Cellular gene; (v) Viral gene.

Alternatively, viral miRNAs can directly target cellular mRNAs involved in host immune response. Viral miRNA ebv-miR-BHRF1-3 targets CXCL11, a T-cell attracting chemokine [121], thus contributing to immune evasion by modulating host's mechanisms of defence. Similar to HCMV, EBV miRNAs can also interfere with MICB. In fact, ebv-miR-BART2-5p has been shown to target this NK cell ligand, hence reducing cell recognition and again contributing for immune evasion [124]. Finally, ebv-miR-BART15 was found to bind NLRP3 in the same site as hsa-miR-223 [130]. NLRP3 (NLR family, pyrin domain containing 3 ; also known as cryopyrin) is a cellular protein that contributes to the production of pro-inflammatory cytokines such as IL-1 $\beta$ and IL-18. Thus, by targeting this cellular 
transcript, EBV reduces immune response, providing an additional mechanism to evade immune response through the expression of its miRNAs.

\subsection{EBV miRNAs Avoid Apoptosis by Targeting Cellular Pro-Apoptotic Genes}

Viral miRNAs play a key role in avoiding cell death, mostly by inhibiting the expression of cellular pro-apoptotic genes [135] (Table 1). One of the best characterized cellular targets of EBV miRNAs is the pro-apoptotic protein PUMA (p53-upregulated modulator of apoptosis) [126]. PUMA is regulated by ebv-miR-BART5-5p, and depletion of this viral miRNA or induction of PUMA expression is sufficient to trigger apoptosis [126]. Another pro-apoptotic protein modulated by EBV is BIM (BCL2 interacting mediator of cell death), a member of BH3-only family proteins. Several EBV-encoded miRNAs from BART-cluster 1 are involved in this regulation, especially ebv-miR-BART1, ebv-miR-BART3, ebv-miR-BART9, ebv-miR-BART11, and ebv-miR-BART12 [122]. Many other cellular pro-apoptotic proteins seem to be modulated by EBV's miRNAs. For example, TOMM22 (translocase of outer mitochondrial membrane 22 homolog), part of the mitochondrial pore receptor complex for the pro-apoptotic protein BAX (BCL2-associated X protein), was identified as a potential target for ebv-miR-BART16 [122]; the BCL2-associated death promoter (BAD) protein, also from the BH3-only pro-apoptotic proteins, is targeted by the viral miRNA ebv-miR-BART20-5p [131]; finally, the pro-apoptotic protein caspase 3 was identified as being a target of ebv-miR-BART16 and ebv-miR-BART1-3p [123]. Together, these findings suggest an important role for EBV miRNAs, avoiding apoptosis both at early stages of infection but also upon cell transformation.

\subsection{EBV-Encoded miRNA ebv-miR-BART6-5p Targets Dicer}

One viral miRNA, ebv-miR-BART6-5p, was found to target Dicer mRNA, reducing the biogenesis of cellular miRNAs $[127,128]$ (Table 1 ). This Dicer interference by a viral miRNA probably results in a negative feedback loop that can act as a tight control for viral and cellular miRNAs [128]. Interestingly, downregulation of Dicer can also serve another purpose, as it has been suggested that Dicer plays a role in EBV reactivation [132] Moreover, ebv-miR-BART6-5p was found to undergo RNA editing that decreases ebv-miR-BART6-5p loading into RISC [128]. This post-transcription editing of pri-miRNA stands as a possible cellular mechanism of defence against viral infection that EBV counteracts by mutating pri-miRNA sequence [128].

\subsection{Cellular miRNAs Regulate EBV Switch from Latent to Lytic Infection}

Several cell-encoded miRNAs modulate the latent/lytic cycles during EBV infection (Table 1). EBV reactivation starts with the expression of BZLF1 viral transcript. This viral transcript is supressed by ZEB1 and ZEB2 host proteins that bind BZLF1 promoter [136,137]. ZEB1 and ZEB2 are targeted by cellular miRNAs from the hsa-miR-200 family. Expression of hsa-miR-200b and hsa-miR-429 has been shown to induce EBV reactivation upon regulation of ZEB proteins [133,134]. Another mechanism modulating EBV reactivation involves the cellular miRNA hsa-miR-let-7a. Apparently, viral protein EBNA1 upregulates hsa-miR-let-7a, which in turn decreases the level of cellular protein Dicer (the target of hsa-miR-let-7a). Since Dicer contributes to EBV reactivation, the induction of hsa-miR-let-7a by EBNA1 promotes EBV latency [132]. Therefore, together with ebv-miR-BART6, hsa-miR-let-7a plays an important role downregulating Dicer, contributing to EBV latency probably by decreasing cellular miRNA levels that can reactivate EBV [127,128,132].

\subsection{EBV miRNAs Target Tumor Suppressor Genes}

Besides cellular proteins related with immune response or apoptotic pathway, some EBV miRNAs were shown to target other cellular mRNAs important for normal cell function. Among these are several tumor-suppressor genes and a key protein of miRNA pathway (Table 1). Viral miRNA interference of tumor-suppressor proteins expression facilitates typical B-cell transformation into indefinitely proliferating lymphoblastoid cell lines as observed upon EBV infection. For example, the EBV-encoded miRNA, ebv-miR-BART3-5p, targets DICE1 (deleted in cancer 1), a tumor-suppressor 
gene; consequently, the expression of ebv-miR-BART3-5p in vitro resulted in the proliferation of host cells [125]. EBV miRNAs also target two other tumor-suppressor genes: ebv-miR-BART19-3p targets WIF1 (WNT inhibitory factor 1), while ebv-miR-BART7 and ebv-miR-BART19-3p target APC (adenomatous polyposis coli) [129]. Additionally, EBV was demonstrated to induce the expression of the oncomir hsa-miR-155 [138,139]. Expression of this well-known cellular miRNA was demonstrated to be crucial for B-cell transformation and proliferation [140]. This complex network of interactions between EBV-encoded miRNAs and their targeted genes provides crucial information on EBV-associated tumorigenesis, as detailed in the following section.

\subsection{EBV miRNAs Play an Important Role in Viral-Induced Carcinomas and Lymphomas}

Several EBV-associated cancers were studied regarding both viral and cellular miRNAs expression profiles. These studies revealed a high inter-tumor variation of viral miRNA expression and posed some challenges, particularly deriving from cellular infiltrates that occur in different tumors and to diverse degrees.

One of the most prominent EBV-associated tumors is NPC. Comparison of the NPC tissue miRNA profile $v s$. non-tumor tissue revealed that $5 \%-19 \%$ of miRNAs expressed in the tumor are EBV-encoded [119]. Although no viral miRNA was found to be consistently expressed in NPC, ebv-miR-BART7-3P, ebv-miR-BART22, and miRNAs from BART-cluster 1 were described as being highly expressed in this kind of tumor $[114,119,141]$. Conversely and despite the inter-tumor variability, all reports indicate the absence of miRNAs from BHRF1-cluster. In addition, several cellular miRNAs were found to be either up- or downregulated in NPC. Among those upregulated, we may mention hsa-miR-17-5p, hsa-miR-320, hsa-miR-652, while the downregulated miRNAs were hsa-miR-15a, hsa-miR-16, hsa-miR-23a/b, and hsa-miR-200c [119]. Since there are several possible targets for these deregulated cellular miRNAs, it is difficult to anticipate the outcome of their decreased or increased expression. It will be interesting to find whether this deregulation of cellular miRNAs is due to EBV infection or if it is a consequence of cellular transformation. Furthermore, it will be important to elucidate these cellular miRNA functions in NPC.

Similarly to NPC, studies concerning GC revealed the predominance of viral miRNAs from BART-clusters and an almost total absence of BHRF1-cluster miRNAs [142,143]. Moreover, several cellular miRNAs were found to be downregulated in GC. Members of the let-7 family and hsa-miR-200 were among the most downregulated host miRNAs. Interestingly, several downregulated cellular miRNAs were tumor-suppressor miRNAs [143]. Taken together, these findings confirm the role of both cellular and viral miRNAs in the well-defined oncogenic potential of EBV.

Alongside NPC and GC, EBV-associated lymphomas were also studied regarding both viral and cellular miRNAs expressions. In DLBCL, viral miRNAs from BART-cluster 2 were slightly more expressed than other viral miRNAs [144]. In contrast, the viral miRNAs ebv-miR-BART7, ebv-miR-BART22, and ebv-miR-BART10 were highly expressed in cells from DLBCL, while ebv-miR-BART15 and ebv-miR-BART20, along with miRNAs derived from BHRF1-cluster, were not detected [144]. Similar to NPC and GC, numerous cellular miRNAs were differentially expressed in EBV-positive and EBV-negative DLBCL. The cellular miRNAs upregulated in EBV-positive DLBCL were hsa-miR-424, hsa-miR-223, hsa-miR-199a, hsa-miR-27b, hsa-miR-378, hsa-miR-26b, and hsa-miR-23a/b. Conversely, miRNAs downregulated were hsa-miR-20b, hsa-miR-221, hsa-miR-151-3p, hsa-miR-222, hsa-miR-29b/c, and hsa-miR-106a. For most of these miRNAs, a role in cancer pathogenesis has been described [12,15], which thereby sustains their role in EBV oncogenesis. Interestingly, Acquired Immunodeficiency Syndrome (AIDS)-related DLBCL cells express high levels of ebv-miR-BART22 and ebv-miR-BHRF1-3, in opposite to cells from immunocompetent patients with DLBCL, suggesting that these miRNAs may play a role in regulation of host cell immune response [121].

Likewise, AIDS-related BL presented a manifest difference regarding miRNA expression depending on EBV latency type. Similar to other EBV type I latency lymphomas and carcinomas, AIDS-related BL did not express miRNAs from BHRF1-cluster, whereas, in the type III latency BL, miRNAs from BHRF1-cluster were abundantly expressed [121]. Interestingly, in both AIDS-related 
lymphomas (DLBCL and BL), BHRF1-cluster expression was accompanied by the detection of LMP1 [121]. Moreover, BHRF1-miRNAs expression is dependent on latency III promoters, and BHRF1 transcripts are induced in lytic cycle activation [145]. Therefore, these data suggest a different behavior of EBV-related lymphomas in immunocompromised patients probably because EBV does not have the need to regulate its gene expression so strongly given the lack of an effective immune response to viral transcripts.

In NKTL, viral miRNAs expressed were similar to other lymphomas: BHRF1-cluster miRNAs were not detected, whereas ebv-miR-BART5 and ebv-miR-BART7-5p were the most highly expressed viral miRNAs [146]. In addition, a group of 15 upregulated and 16 downregulated cellular miRNAs were detected. Among downregulated cellular miRNAs were hsa-miR-142-3p, which targets the pro-inflammatory IL-1 $\alpha$, and hsa-miR-205, which targets the oncogenic protein BCL6 [146].

Recent studies suggest that EBV miRNAs can also play an important role in cancer progression. For instance, ebv-miR-BART-7-3p, highly regulated in NPC, was shown to target tumor-suppressor phosphatase and tensin homolog (PTEN), modulating PI3K/Akt/GSK-3 $\beta$ signaling, resulting in epithelial to mesenchymal transition and favoring metastasis [147]. A similar mechanism was suggested for ebv-miR-BART1, which also targets PTEN [148]. These two findings reinforce the idea that viral miRNAs are redundant and sometimes share cellular targets to ensure its repression. In addition to these findings, all viral miRNAs from BART-cluster 2 were also demonstrated to target $\mathrm{N}$-myc downstream regulated 1 (NDRG1) cellular transcript [149]. NDRG1 encodes a suppressor of metastasis and an epithelial differentiation marker, and its suppression may avoid cell growth arrest and terminal differentiation, providing EBV with a new mechanism for EBV-mediated carcinogenesis [149]. Taken together, all these findings demonstrate that EBV miRNAs are important to explain viral oncogenic properties.

\subsection{EBV Is Able to Transfer Viral miRNAs through Exosomes}

EBV infection of target cells can induce the transfer of miRNAs and proteins via exosomes [150,151]. The release of these exosomes was observed in cells from NPC [152], and they transported miRNAs from all different clusters as well as LMP1 protein [151]. Viral miRNAs were capable of targeting mRNAs in neighbor cells and probably even more distant cells, as these exosomes were detectable in serum samples [152]. These findings may help to explain the occurrence of multiple sclerosis and its association with EBV. In fact, almost all cases of multiple sclerosis are found in EBV-positive patients. However, the absence of viral DNA in inflammatory lesions caused by this disease has challenged the link between EBV and multiple sclerosis; even so, it is possible that viral miRNAs carried by exosomes provide a mechanism that could explain the role of EBV in multiple sclerosis etiology [153-157].

In conclusion, the complex interactions between EBV miRNAs, host proteins, and host miRNAs contribute largely for viral latency and help the onset of lifelong infection of $\mathrm{EBV}$, similarly to other herpesvirus. Moreover, EBV miRNAs play an important role in immune evasion, cell transformation, and proliferation. Therefore, viral miRNAs contribute, together with several other viral proteins, to oncogenic processes and help to explain EBV-associated B-cell lymphomas as well as carcinomas. Interestingly, miRNAs carried by exosomes can be the missing link between EBV and multiple sclerosis.

\section{Human Herpesvirus 8/Kaposi's Sarcoma-Associated Herpes Virus (HHV-8/KSHV) Encodes 25 Mature miRNAs}

Human herpesvirus 8 (HHV-8)-also known as Kaposi's sarcoma-associated herpes virus (KSHV)—is a herpesvirus from the Gammaherpesvirinae subfamily. KSHV is known as the etiologic agent of several cancers, such as Kaposi's sarcoma (KS), primary effusion lymphoma (PEL), and multicentric Castleman's disease (MCD), particularly in immunosuppressed patients (e.g., HIV-infected patients and solid organ transplant recipients undergoing immunosuppressive treatment) [39,158]. Like all herpesviruses, KSHV establishes a latent infection in various cell types, namely in monocytes, dendritic cells, B-lymphocytes, and endothelial cells. KSHV encodes 13 pre-miRNAs, originating 
25 mature miRNA sequences. These 13 pre-miRNAs are unevenly distributed throughout the KSHV genome (Figure 4). kshv-miR-K12-1 to kshv-miR-K12-9 and kshv-miR-K12-11 are encoded within K12 intron, while kshv-miR-K12-10a,b is located within the K12 ORF, and kshv-miR-K12-12 is transcribed within the 3'UTR of K12 [78,159,160]. Expression levels of KSHV miRNAs vary considerably [159], and, while some are highly conserved (e.g., kshv-miR-K12-1, kshv-miR-K12-3, kshv-miR-K12-8, kshv-miR-K12-10, kshv-miR-K12-11, and kshv-miR-K12-12), others exhibit alterations that may affect the respective processing and function [161,162]. Moreover, these polymorphisms may correlate with KS risk [163].
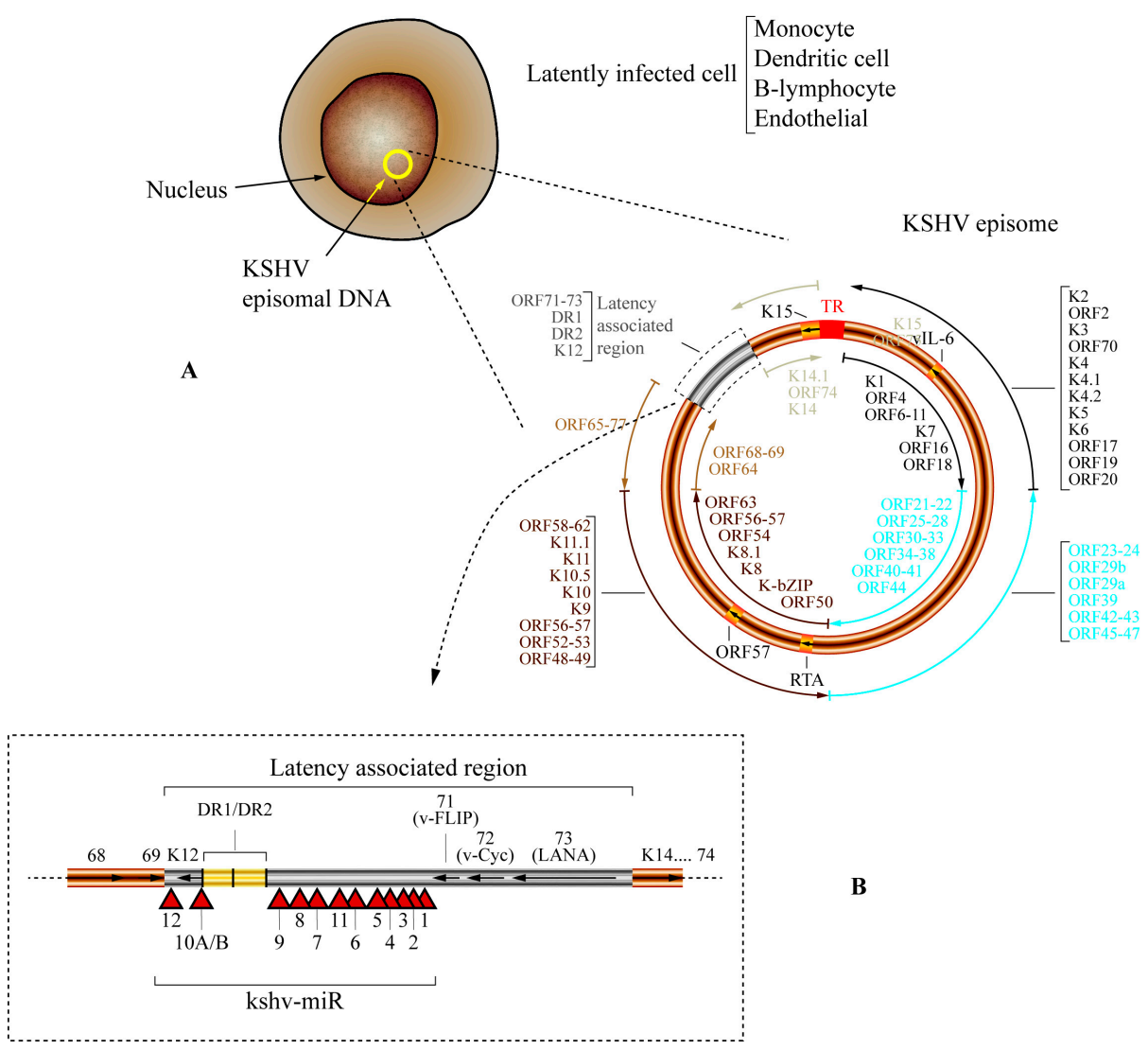

B

Figure 4. Genome organization and location of miRNA encoded by Kaposi's sarcoma-associated herpesvirus (KSHV) (HHV-8). (A) After primary infection, KSHV establishes a latent infection in monocytes, dendritic cells, B-lymphocytes, and endothelial cells. During latency, the KSHV genome is maintained as a circular episome (represented as a yellow circle inside the nucleus). The general structure of episomal DNA is presented, and the relative positions of the open reading frames (ORFs) are shown. The grey box represents the latency-associated region. The terminal repeat (TR) region is represented by a red box, and the ORFs encoding for viral interleukin 6 (vIL-6), the replication and transcription activator (RTA), ORF57, and K15 are represented by light orange boxes. The outer circular arrows refer to the ORFs that are transcribed in antisense orientation, while the inner circular arrows refer to those that are transcribed in the opposite orientation. To facilitate the representation of the different ORFs and their relative location, and the outer and inner circular arrows are presented in different colors (black, light blue, brown, light brown and light grey); (B) Genomic location of miRNAs encoded by KSHV (kshv-miR). A linear representation of the latency-associated region (grey box) of the KSHV genome is shown, and the locations of miRNA precursors are denoted by red triangles. The positions of ORFs 68, 69, K12, 71 (v-FLIP), 72 (v-Cyc), 73 (LANA), K14, and 74 are also shown; arrows inside each ORF indicate the direction of transcription. The two adjacent yellow boxes represent the DR1/DR2 region. 
KSHV miRNAs seem to play a role in viral pathogenesis in a disease-specific manner and it is possible that viral miRNAs exhibit different functions depending on the infected cell's type [39]. KSHV miRNAs target multiple cellular genes important to normal cell functioning. Furthermore, KSHV miRNAs contribute to immune evasion and modulation, avoid apoptosis, and contribute to tumorigenesis (Table 2). Besides miRNAs, other viral proteins interfere with cellular miRNAs and their functions.

Table 2. MicroRNAs with potential role in KSHV infection and pathogenesis.

\begin{tabular}{|c|c|c|c|}
\hline $\begin{array}{l}\text { KSHV-Encoded miRNA } \\
\text { (kshv-miR-) }\end{array}$ & Target * & Predicted Role & References \\
\hline \multirow{5}{*}{ K12-1 } & MICB & Immune evasion & [124] \\
\hline & p21 & Oncogenesis & [164] \\
\hline & IкB $\alpha$ & $\begin{array}{c}\text { Cell survival } \\
\text { Modulates latent/lytic infection }\end{array}$ & $\begin{array}{l}{[165]} \\
{[166]}\end{array}$ \\
\hline & Caspase 3 & Cell survival & [167] \\
\hline & $\mathrm{xCT}$ expression & Facilitates viral entry & [168-171] \\
\hline \multirow[t]{3}{*}{ K12-3 } & $\mathrm{C} / \mathrm{EBP} \beta$ & $\begin{array}{l}\text { Immune evasion } \\
\text { Cell survival } \\
\text { Oncogenesis }\end{array}$ & $\begin{array}{l}{[158,168]} \\
{[158,168]} \\
{[158,168]}\end{array}$ \\
\hline & Caspase 3 & Cell survival & [167] \\
\hline & NFIB & Modulates latent/lytic infection & [172] \\
\hline \multirow{2}{*}{ K12-4 } & RBL2 & Modulates latent/lytic infection & [173] \\
\hline & Caspase 3 & Cell survival & [167] \\
\hline \multirow{2}{*}{ K12-5 } & BCLAF1 & Modulates latent/lytic infection & {$[174]$} \\
\hline & MYD88 & Immune evasion & [175] \\
\hline K12-6 & $\mathrm{xCT}$ expression & Facilitates viral entry & [168-171] \\
\hline \multirow[t]{2}{*}{ K12-7 } & $\mathrm{C} / \mathrm{EBP} \beta$ & $\begin{array}{l}\text { Immune evasion } \\
\text { Cell survival } \\
\text { Oncogenesis }\end{array}$ & $\begin{array}{l}{[168]} \\
{[168]} \\
{[168]}\end{array}$ \\
\hline & KSHV ORF50 & Modulates latent/lytic infection & {$[176,177]$} \\
\hline \multirow{4}{*}{ K12-9 } & IRAK1 & Immune evasion & [175] \\
\hline & $\mathrm{xCT}$ expression & Facilitates viral entry & [168-171] \\
\hline & KSHV ORF50 & Modulates latent/lytic infection & {$[176,177]$} \\
\hline & BCLAF1 & Modulates latent/lytic infection & [174] \\
\hline \multirow{2}{*}{ K12-10 } & TWEAKR & $\begin{array}{l}\text { Immune evasion } \\
\text { Cell survival }\end{array}$ & $\begin{array}{l}{[178]} \\
{[178]}\end{array}$ \\
\hline & TGFBR2 & $\begin{array}{l}\text { Cell survival } \\
\text { Oncogenesis }\end{array}$ & $\begin{array}{l}{[166]} \\
{[166]}\end{array}$ \\
\hline \multirow{4}{*}{ K12-11 } & $\mathrm{IKK} \varepsilon$ & $\begin{array}{c}\text { Immune evasion } \\
\text { Modulates latent/lytic infection }\end{array}$ & $\begin{array}{l}{[179]} \\
{[179]}\end{array}$ \\
\hline & $\mathrm{C} / \mathrm{EBP} \beta$ & $\begin{array}{l}\text { Immune evasion } \\
\text { Cell survival } \\
\text { Oncogenesis }\end{array}$ & $\begin{array}{l}{[180]} \\
{[180]} \\
{[180]}\end{array}$ \\
\hline & SMAD5 & $\begin{array}{l}\text { Cell survival } \\
\text { Oncogenesis }\end{array}$ & $\begin{array}{l}{[181]} \\
{[181]}\end{array}$ \\
\hline & xCT expression & Facilitates viral entry & [168-171] \\
\hline
\end{tabular}

* Detailed information on potential targets is mentioned in the text. Abbreviations used: BCLAF1-BCL2-associated transcription factor 1; C/EBP $\beta$ - CCAAT/enhancer binding protein beta; IkB $\alpha$-nuclear factor of kappa light polypeptide gene enhancer in B-cells inhibitor, alpha; IKK $\varepsilon$-IкB kinase epsilon; IRAK1—interleukin 1 receptor-associated kinase 1; KSHV ORF50-Kaposi's sarcoma-associated herpesvirus open reading frame 50; MICB - major histocompatibility complex class-I related chain B; MYD88-myeloid differentiation primary response 88; NFIB-nuclear factor I/B; p21—cyclin-dependent kinase inhibitor 1A; RBL2—retinoblastoma-like protein 2; SMAD5-SMAD family member 5; TGFBR2-transforming growth factor, beta-receptor II; TWEAKR - tumor necrosis factor-like weak inducer of apoptosis receptor; xCT-solute carrier family 7 (anionic amino acid transporter light chain, xC- system), member 11. 


\subsection{KSHV miRNAs Target Cellular mRNAs to Evade Immune Response and Modulate Cytokines Response}

KSHV-encoded miRNAs can inhibit innate immune response. kshv-miR-K12-9 targets IRAK1 (interleukin-1 receptor-associated kinase 1) while kshv-miR-K12-5 targets MYD88 (myeloid differentiation primary response 88). Both IRAK1 and MYD88 mediate TLR/IL-1R signaling, and their repression results in reduced inflammation [175]. Furthermore, kshv-miR-K12-11 targets IkB kinase epsilon $(\mathrm{IKK} \varepsilon)$, resulting in attenuated type I interferon signaling [179]. Similar to HCMV and EBV, KSHV evades NK cell recognition and killing by encoding a miRNA, kshv-miR-K12-1, that targets MICB mRNA [124].

In addition to the modulation of NK cell recognition, KSHV also modulates cytokine secretion. One viral miRNA, kshv-miR-K12-10, targets the tumor necrosis factor-like weak inducer of the apoptosis receptor (TWEAKR). Repression of TWEAKR reduces interactions with its ligand, resulting in reduced expression of IL-8 and monocyte chemoattractant protein 1 (MCP-1) [178]. Moreover, kshv-mir-K12-3 and kshv-miR-K12-7 repress C/EBP $\beta$ (CCAAT/enhancer-binding protein $\beta$ ), a transcriptional repressor of IL-6 and IL-10 [168], two cytokines that promote cell growth of KSHV-infected cells, and angiogenesis [158]. However, it remains unclear if these two viral miRNAs target C/EBP $\beta$ directly or indirectly by targeting other upstream factors [158]. In contrast, kshv-miR-K12-11 directly targets C/EBP $\beta$ and has been shown to contribute to splenic B-cell expansion and KSHV-associated lymphomagenesis [180]. Therefore, it is well established that KSHV miRNAs cooperatively regulate cytokine expression to facilitate infection and oncogenesis while avoiding the host immune system.

\subsection{KSHV-Encoded miRNAs Regulate Cell Growth and Survival}

KSHV is a well-known oncogenic virus. Therefore, its ability to avoid cell death and promote cell cycle progression and cell growth is closely related with KSHV-induced cell transformation. KSHV contributes to these functions by targeting key cellular proteins involved in these pathways. For example, kshv-miR-K12-1 targets the cellular cyclin-dependent kinase inhibitor p21 to promote cell cycle progression [164]. The same viral miRNA was also shown to interfere with $\mathrm{I \kappa B} \alpha$, activating the NFKB pathway [165], which contributes to cell survival. Similarly, kshv-miR-K12-10 targets TWEAKR, conferring resistance to TWEAK-induced apoptosis, which is normally mediated by TWEAK/TWEAKR interactions [178]. In addition, this viral miRNA also interferes with transforming growth factor beta (TGF- $\beta$ ) receptor II (TGFBR2), affecting the TGF- $\beta$ pathway [166]. Interestingly, the same pathway is also targeted by another viral miRNA, kshv-miR-K12-11, which targets SMAD5 (SMAD family member 5 ), an intermediate in the TGF- $\beta$ pathway [181]. This inhibition of the TGF- $\beta$ pathway ultimately results in increased cell survival and virally induced oncogenesis $[166,181]$.

Viral-driven cell transformation and oncogenesis relies heavily on the ability to avoid apoptosis. Therefore, unsurprisingly, three other viral miRNAs, kshv-miR-K12-1, kshv-miR-K12-3, and kshv-miR-K12-4-3p, cooperatively suppress caspase 3 by binding its $3^{\prime} U T R$ and reducing apoptosis in infected cells [167]. Furthermore, several viral miRNAs regulate cellular transcription-factors that indirectly protect infected cells from reactive nitrogen and oxygen species-induced apoptosis [168,169].

An obvious conclusion is that KSHV-encoded miRNAs target multiple pathways related to cell survival. Interestingly, some viral miRNAs target multiple pathways, and the same pathway can be targeted by multiple viral miRNAs. This evidences the redundancy of viral miRNA functions and the importance of KSHV miRNAs in cell transformation and oncogenesis. In fact, some studies have shown that KSHV mutants lacking 10 viral miRNAs encoded in K12 intron failed to transform infected cells and ultimately induced cell apoptosis [182].

\subsection{KSHV miRNAs Facilitate Virus Entry}

Several miRNAs were associated with increased susceptibility to KSHV infection. Among them, kshv-miR-K12-1, kshv-miR-K12-9, and kshv-miR-K12-11 were shown to increase xCT expression, a fusion-entry receptor for KSHV, increasing macrophage and endothelial cell susceptibility to KSHV [168]. Consistently, kshv-miR-K12-11 has been shown to target BACH-1 (BTB and CNC homology 1) 
which, in turn, is a negative regulator of xCT [170,171]. Several viral miRNAs-in particular kshv-miR-K12-11 and kshv-miR-K12-6 - cooperatively downregulate a cellular transcription-factor MAF (v-maf avian musculoaponeurotic fibrosarcoma oncogene homolog) [169]. MAF also negatively regulates $\mathrm{XCT}$, underlining the cooperative and redundant action of viral miRNAs. These findings point to a KSHV evolutionary strategy that promotes infection by increasing cell susceptibility to virus entry [158], a crucial step in viral replication cycle.

\subsection{KSHV miRNAs Target Viral Transcripts to Regulate Latent and Lytic Infection}

Similar to other herpesviruses included in this review, KSHV miRNAs also target viral and cellular mRNAs to promote latency. kshv-miR-K12-7 and kshv-miR-K12-9 target immediate-early gene ORF50, decreasing the expression of the replication and transcription activator (RTA) encoded within this viral gene [176,177] (Figure 4). Additionally, kshv-miR-K12-4 repress the retinoblastoma-like protein 2 (RBL2) that indirectly maintains methylation of the RTA promoter and consequently reduces expression of this viral gene [173]. Another viral miRNA that impairs RTA expression is kshv-miR-K12-3. This KSHV-encoded miRNA targets the nuclear factor I/B (NFIB), known to act as a RTA activator [172]. The RTA protein is essential for initiation of lytic replication of KSHV; therefore, interfering with this viral transcript promotes viral latency. Lastly, kshv-miR-K12-1 also contributes to latency by targeting $\mathrm{I} \kappa \mathrm{B} \alpha$, as previously mentioned, which leads to NF $\kappa \mathrm{B}$-dependent viral latency [166].

Conversely, viral miRNAs can also induce lytic replication cycle, essential for spreading the infection. Targeting of BCLAF1 (BCL2-associated transcription factor 1) by kshv-miR-K12-5 and kshv-miR-K12-9 promotes lytic replication through unknown mechanisms [174]. Moreover, kshv-miRK12-11 repression of IKK $\varepsilon$ also contributes to lytic reactivation of KSHV [179]. In addition, chemical induction of KSHV reactivation revealed upregulation of kshv-miR-K12-10 and kshv-miR-k12-12, suggesting that these viral miRNAs may also play a role in KSHV lytic reactivation [162].

Taken together, these findings evidence the importance of viral miRNAs in the regulation of KSHV lytic and latent infection. Apparently, viral miRNAs predominantly promote latent infection. This observation is in agreement with miRNAs' location within the KSHV genome: all of them are encoded within the latency-associated region [159].

\subsection{KSHV Encodes Orthologues of Cellular miRNAs}

Three viral miRNAs share perfect seed homology with cellular miRNAs [170,171,183,184]. For instance, kshv-miR-K12-10 is a viral orthologue of hsa-miR-142-3p. Interestingly, kshv-miR-K12-10 can be processed into four different functional variants. In PEL cells, hsa-miR-142-3p presented a very similar processing pattern, and hsa-miR-142-3p variants' seed sequence matched those from kshv-miR-K12-10 variants $[166,183]$. Viral and cellular miRNAs were shown to target TGF- $\beta$ type II receptor, inhibiting the TGF- $\beta$ pathway [166]. In addition, kshv-miR-K12-11 shares seed sequence with hsa-miR-155 [170,171], a well-known oncomir [185]. Again, both miRNAs are known to target IKK $\varepsilon$, C $/$ EBP $\beta$, BACH-1, and SMAD5 [168,179-181,185]. Lastly, kshv-miR-K12-3 was found to share seed sequence homology with hsa-miR-23. Moreover, cellular and viral miRNAs were shown to share targets, such as caspase 3 and caspase 7, linking these two miRNAs with anti-apoptotic functions [184]. By encoding orthologues, KSHV is able to ensure the correct expression of key miRNAs necessary for viral infection and persistence. Moreover, by sharing seed sequences with cellular miRNAs, these viral miRNAs can be directed to the same targets as host miRNAs but can also target other genes and vice versa, adding an increased layer of complexity to viral miRNA regulation of host genes.

\subsection{Cellular miRNAs Play a Key Role in KSHV Pathology}

Considering the many functions of the cellular miRNAs, it is no surprise that KSHV-mediated deregulation of these miRNAs can contribute to viral pathogenesis [186]. Deregulation of cellular miRNAs may promote KSHV-associated cancers, immune modulation, and regulation of the viral replication cycle [186]. 
A viral protein, K15 (Figure 4), has been shown to upregulate the expression of hsa-miR-21 and hsa-miR-31 [187]. These two miRNAs promote cell migration, angiogenesis, and lymphangiogenesis, indicating an important role in the development of cancer, especially in metastatic processes [187]. Remarkably, cellular miRNAs from the hsa-miR-221/hsa-miR-222 cluster were found to be greatly downregulated in KSHV-infected cells. Viral latency-associated nuclear antigen (LANA) and Kaposin B are thought to mediate the repression of these cellular miRNAs, which results in increased cell migration [188]. Moreover, KSHV was also found to downregulate hsa-miR-30b/c. These two cellular miRNAs target Delta-like 4 (DLL4), a protein involved in vascular development and angiogenesis [189]. Interestingly, all these miRNAs were previously identified as either oncogenes or tumor-suppressor genes in several types of cancer [186]. Thus, KSHV-mediated deregulation of this cellular miRNAs appears to play an important role in viral oncogenesis.

An important cellular chemokine receptor, CXCR4, is targeted by hsa-miR-146a. These cellular miRNAs is overexpressed in response to NFKB activation by viral FLICE inhibitory protein (vFLIP; Figure 4) [190]. Interestingly, repression of CXCR4 appears to contribute to KS by promoting the premature release of endothelial cell progenitors infected with KSHV into the blood stream [190]. In addition to promoting IL- 6 expression by miRNA-mediated repression of C/EBP $\beta$ (mentioned earlier in this review), KSHV also encodes a viral interleukin 6 (vIL-6; Figure 4) that mimics its human cognate. IL-6 and vIL-6 are targeted by hsa-miR-608 and hsa-miR-1293, respectively [191]. Remarkably, the viral ORF57 protein (Figure 4) has been shown to compete with these two cellular miRNAs for the binding sites in IL- 6 and vIL-6 mRNAs, avoiding RISC-mediated suppression of both mRNAs [192]. The expression pattern of cellular miRNAs upon KSHV infection revealed that hsa-miR-146a, hsa-miR-31, and hsa-miR-132 peaked at 6 hours post-infection, while hsa-miR-193a and hsa-miR-let-7i steadily increased over $72 \mathrm{~h}$ post-infection [193]. Moreover, hsa-miR-132, one of the upregulated cellular miRNAs, has been shown to repress interferon-stimulated genes by targeting p300 transcriptional co-activator [193].

There is little evidence that cellular miRNAs can regulate KSHV lytic or latent infection by targeting viral transcripts. However, studies that considered the influence of HIV-1 Nef protein on the KSHV replication provided interesting insights regarding the role that cellular miRNAs may play in KSHV latent and lytic infection [194]. For example, hsa-miR-1258 was confirmed to target RTA $3^{\prime}$ UTR downregulating this reactivation factor, resulting in the reduction of KSHV reactivation [194]. Additionally, two other cellular miRNAs were able to target RTA 3'UTR (i.e., hsa-miR-498 and hsa-miR-320d), promoting KSHV latency by repressing the RTA [195]. Interestingly, these two miRNAs are downregulated by HSV-1 infection, providing another mechanism modulating the KSHV lytic/latent cycles. Nevertheless, this kind of mechanism imposes the coexistence of both viruses in the same body compartment, which is not obvious, at least in the case of HSV-1 and KSHV, except during occasional HSV-1 viremia [195].

\section{Conclusions}

Interactions between virus and host are intricate, and miRNAs add yet another layer of complexity to them. In addition to encoding miRNAs, viruses can also deregulate cellular miRNAs to facilitate infection. By up- or downregulating key cellular miRNAs, viruses alter cellular gene expression to achieve similar results to those of viral miRNA targeting. Viral transcripts can also be targeted by cellular miRNAs with different outcomes. Generally, these cellular miRNAs repress viral gene expression, resulting in decreased viral replication.

Members of the Herpesviridae family are relevant examples of this complex and dynamic process where cellular and viral factors interact, resulting in lifelong viral infection. By targeting cellular mRNAs, herpesvirus miRNAs were reported to regulate genes related with immune response, apoptosis, cell cycle control, cell differentiation, and intracellular traffic. As many of these altered pathways are of the utmost importance for cellular homeostasis, their alterations largely contribute to viral pathogenesis. 
The most noteworthy pathological event triggered by viral miRNAs is oncogenesis. In fact, oncogenic viruses such as EBV and KSHV/HHV-8 encode viral miRNAs that can be directly linked with the development of malignancies. Remarkably, although having different sequences, some EBV- and KSHV-encoded miRNAs (e.g., ebv-miR-BART2-5p and kshv-miR-K12-7) are able to repress identical targets (i.e., MICB), thus contributing to a similar outcome (i.e., reduced NK cell recognition and immune evasion). Moreover, while EBV induces hsa-miR-155 expression, KSHV encodes an orthologue for the same oncomir. Therefore, despite being evolutionarily distant, EBV and KSHV evolved separately and developed distinct strategies to achieve similar results: an establishment of lifelong infection, immune evasion, and ultimately host cell transformation.

This exciting new field may hold some answers as to why some viruses such as herpesvirus are so successful in infecting and establishing lifelong infections in human hosts. It could also help us decipher the molecular mechanisms underlying some important pathologies derived from herpesvirus infection, such as cancer.

This review has focused the interactions between herpesviruses, human host, and miRNAs; a word of caution should be added: the interplay between viral infection and miRNAs constitutes a field where part of the information relies on putative or indirect interactions. These interactions potentially dictate up- or downregulation of cell proteins that are key players in distinct cell pathways. However, miRNA-mRNA interactions are more complex than the mere base pairing mechanism between the seed region of the miRNA and the sequence of its target mRNA [51,196,197]. The prediction of such binding sites relies on algorithms based on base-pair complementarity but the potencial changes in the target gene expression induced by miRNAs imposes powerful and reliable experimental methods. In vitro studies based on the overexpression or inhibition of the miRNA of interest followed by the analysis of putative affected genes, although useful to confirm the computational miRNA target prediction, could yield false positive results, thus imposing the development of new strategies and more accurate experimental approaches.

Although not the subject of this review, it is important to emphasize that, during the last few years, several techniques (e.g., CLASH, RIP-CHIP, HITS-CLIP, PAR-CLIP, and proteomics analysis) have been used to functionally validate the targets of several viral miRNAs, particularly for those encoded by herpesviruses [94,183,198-205]. These new technologies allow unprecedented and largely unbiased views into miRNAs-mediated regulation of gene expression in virus-infected cells. In addition, it is of paramount importance that studies using in vivo models of infection are performed in order to confirm data obtained in in vitro experiments [206,207]. Notably, in the context of herpesvirus infection, there is little evidence from in vivo data regarding the role of viral-encoded miRNAs in the regulation of latent/lytic cycles of infection [62,208], either because they are context-dependent or due to insufficient sensitivity of the detection assay. Undoubtedly, further studies using different approaches and technologies are required towards the clear definition of miRNAs targetome and their functional relevance in viral infection, latency, and pathogenesis.

Finally, despite our limited knowledge, it is obvious that miRNAs constitute a potential therapeutic approach to viral infections and their pathological consequences. In fact, some advances have already been made in the development of therapeutic miRNAs against hepatitis $C$ virus infection [108].

Author Contributions: Diogo Piedade and José Miguel Azevedo-Pereira conceived and wrote the manuscript.

Conflicts of Interest: The authors declare no conflict of interest.

\section{Abbreviations}

The following abbreviations are used in this manuscript:

AIDS

APC

ATP5B

ATP6V0CP1
Acquired immunodeficiency syndrome

Adenomatous polyposis coli

Mitochondrial ATP synthase subunit beta

ATPase, $\mathrm{H}^{+}$transporting, lysosomal $16 \mathrm{kDa}$, V0 subunit $\mathrm{C}$ pseudogene 1 


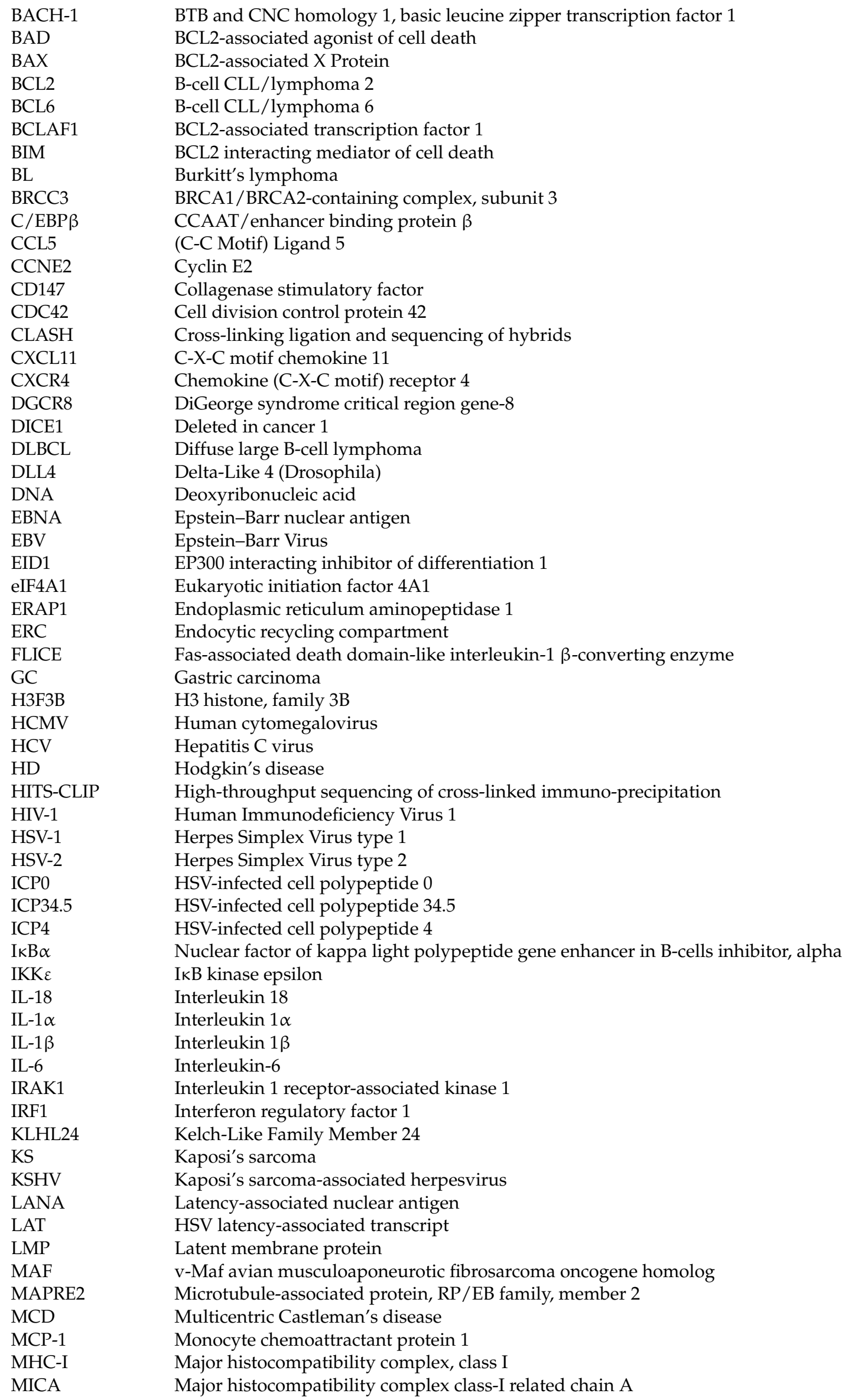




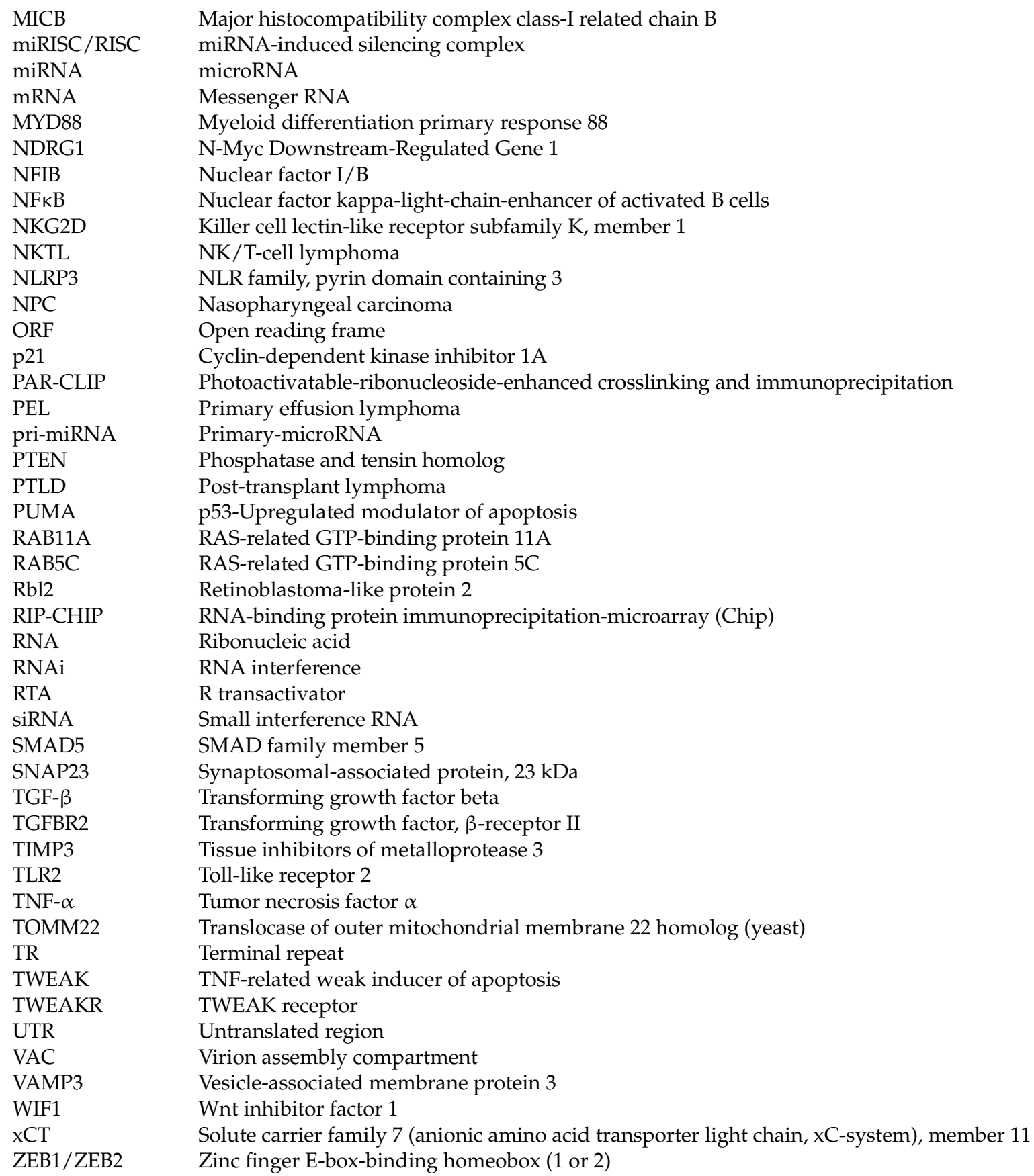

\section{References}

1. Bushati, N.; Cohen, S.M. microRNA functions. Annu. Rev. Cell. Dev. Biol. 2007, 23, 175-205. [CrossRef] [PubMed]

2. Kloosterman, W.P.; Plasterk, R.H.A. The Diverse Functions of MicroRNAs in Animal Development and Disease. Dev. Cell 2006, 11, 441-450. [CrossRef] [PubMed]

3. Doench, J.G.; Petersen, C.P.; Sharp, P.A. siRNAs can function as miRNAs. Genes Dev. 2003, 17, 438-442. [CrossRef] [PubMed]

4. Bartel, D.P. MicroRNAs: Genomics, Biogenesis, Mechanism, and Function. Cell 2004, 116, 281-297. [CrossRef]

5. Lee, R.C.; Feinbaum, R.L.; Ambros, V. The C. elegans heterochronic gene lin-4 encodes small RNAs with antisense complementarity to lin-14. Cell 1993, 75, 843-854. [CrossRef]

6. Wightman, B.; Ha, I.; Ruvkun, G. Posttranscriptional regulation of the heterochronic gene lin-14 by lin-4 mediates temporal pattern formation in C. elegans. Cell 1993, 75, 855-862. [CrossRef] 
7. Valencia-Sanchez, M.A.; Liu, J.; Hannon, G.J.; Parker, R. Control of translation and mRNA degradation by miRNAs and siRNAs. Genes Dev. 2006, 20, 515-524. [CrossRef] [PubMed]

8. Pillai, R.S.; Bhattacharyya, S.N.; Filipowicz, W. Repression of protein synthesis by miRNAs: How many mechanisms? Trends Cell. Biol. 2007, 17, 118-126. [CrossRef] [PubMed]

9. Nilsen, T.W. Mechanisms of microRNA-mediated gene regulation in animal cells. Trends Genet. 2007, 23, 243-249. [CrossRef] [PubMed]

10. Friedman, R.C.; Farh, K.K.-H.; Burge, C.B.; Bartel, D.P. Most mammalian mRNAs are conserved targets of microRNAs. Genome Res. 2009, 19, 92-105. [CrossRef] [PubMed]

11. Kozomara, A.; Griffiths-Jones, S. miRBase: Annotating high confidence microRNAs using deep sequencing data. Nucleic Acids Res. 2014, 42, D68-D73. [CrossRef] [PubMed]

12. Esquela-Kerscher, A.; Slack, F.J. Oncomirs-microRNAs with a role in cancer. Nat. Rev. Cancer 2006, 6, 259-269. [CrossRef] [PubMed]

13. Chang, T.-C.; Mendell, J.T. microRNAs in Vertebrate Physiology and Human Disease. Annu. Rev. Genom. Hum. Genet. 2007, 8, 215-239. [CrossRef] [PubMed]

14. Krützfeldt, J.; Stoffel, M. MicroRNAs: A new class of regulatory genes affecting metabolism. Cell Metab. 2006, 4, 9-12. [CrossRef] [PubMed]

15. Farazi, T.A.; Spitzer, J.I.; Morozov, P.; Tuschl, T. miRNAs in human cancer. J. Pathol. 2011, 223, $102-115$. [CrossRef] [PubMed]

16. Lakatos, L.; Szittya, G.; Silhavy, D.; Burgyán, J. Molecular mechanism of RNA silencing suppression mediated by p19 protein of tombusviruses. EMBO J. 2004, 23, 876-884. [CrossRef] [PubMed]

17. Vance, V.; Vaucheret, H. RNA silencing in plants-defense and counterdefense. Science 2001, 292, $2277-2280$. [CrossRef] [PubMed]

18. Katze, M.G.; He, Y.; Gale, M., Jr. Viruses and interferon: a fight for supremacy. Nat. Rev. Immunol. 2002, 2, 675-687. [CrossRef] [PubMed]

19. Elbashir, S.M.; Harborth, J.; Lendeckel, W.; Yalcin, A.; Weber, K.; Tuschl, T. Duplexes of 21-nucleotide RNAs mediate RNA interference in cultured mammalian cells. Nature 2001, 411, 494-498. [CrossRef] [PubMed]

20. Cullen, B.R. How Do Viruses Avoid Inhibition by Endogenous Cellular MicroRNAs? PLoS Pathog. 2013, 9 , 12-14. [CrossRef] [PubMed]

21. Lu, S.; Cullen, B.R. Adenovirus VA1 noncoding RNA can inhibit small interfering RNA and MicroRNA biogenesis. J. Virol. 2004, 78, 12868-12876. [CrossRef] [PubMed]

22. Bennasser, Y.; Yeung, M.L.; Jeang, K.-T. HIV-1 TAR RNA Subverts RNA Interference in Transfected Cells through Sequestration of TAR RNA-binding Protein, TRBP. J. Biol. Chem. 2006, 281, 27674-27678. [CrossRef] [PubMed]

23. Harwig, A.; Das, A.T.; Berkhout, B. Retroviral microRNAs. Curr. Opin. Virol. 2014, 7, 47-54. [CrossRef] [PubMed]

24. Grundhoff, A.; Sullivan, C.S. Virus-encoded microRNAs. Virology 2011, 411, 325-343. [CrossRef] [PubMed]

25. Luna, J.M.; Scheel, T.K.H.; Rice, C.M.; Darnell, R.B. Hepatitis C Virus RNA Functionally Sequesters miR-122. Cell 2015, 160, 1099-1110. [CrossRef] [PubMed]

26. Lecellier, C.H.; Dunoyer, P.; Arar, K.; Lehmann-Che, J.; Eyquem, S.; Himber, C.; Saib, A.; Voinnet, O. A cellular microRNA mediates antiviral defense in human cells. Science 2005, 308, 557-560. [CrossRef] [PubMed]

27. Bai, X.T.; Nicot, C. miR-28-3p is a cellular restriction factor that inhibits human T cell leukemia virus, type 1 (HTLV-1) replication and virus infection. J. Biol. Chem. 2015, 290, 5381-5390. [CrossRef] [PubMed]

28. Delorme-Axford, E.; Donker, R.B.; Mouillet, J.-F.; Chu, T.; Bayer, A.; Ouyang, Y.; Wang, T.; Stolz, D.B.; Sarkar, S.N.; Morelli, A.E.; et al. Human placental trophoblasts confer viral resistance to recipient cells. Proc. Natl. Acad. Sci. USA 2013, 110, 12048-12053. [CrossRef] [PubMed]

29. Frappier, L. Regulation of Herpesvirus Reactivation by Host MicroRNAs. J. Virol. 2015, 89, $2456-2458$. [CrossRef] [PubMed]

30. Cullen, B.R. Herpesvirus microRNAs: Phenotypes and functions. Curr. Opin. Virol. 2011, 1, $211-215$. [CrossRef] [PubMed]

31. Kincaid, R.P.; Sullivan, C.S. Virus-Encoded microRNAs: An Overview and a Look to the Future. PLoS Pathog. 2012, 8, e1003018. [CrossRef] [PubMed]

32. Sun, L.; Li, Q. The miRNAs of herpes simplex virus (HSV). Virol. Sin. 2012, 27, 333-338. [CrossRef] [PubMed]

33. Hook, L.; Hancock, M.; Landais, I.; Grabski, R.; Britt, W.; Nelson, J.A. Cytomegalovirus microRNAs. Curr. Opin. Virol. 2014, 7, 40-46. [CrossRef] [PubMed] 
34. Barth, S.; Meister, G.; Grässer, F.A. EBV-encoded miRNAs. Biochim. Biophys. Acta 2011, 1809, 631-640. [CrossRef] [PubMed]

35. Gottwein, E. Kaposi's Sarcoma-Associated Herpesvirus microRNAs. Front. Microbiol. 2012, 3, 165. [CrossRef] [PubMed]

36. Zhu, Y.; Haecker, I.; Yang, Y.; Gao, S.-J.; Renne, R. $\gamma$-Herpesvirus-encoded miRNAs and their roles in viral biology and pathogenesis. Curr. Opin. Virol. 2013, 3, 266-275. [CrossRef] [PubMed]

37. Boss, I.W.; Renne, R. Viral miRNAs and immune evasion. Biochim. Biophys. Acta 2011, 1809, 708-714. [CrossRef] [PubMed]

38. Kuzembayeva, M.; Hayes, M.; Sugden, B. Multiple functions are mediated by the miRNAs of Epstein-Barr virus. Curr. Opin. Virol. 2014, 7, 61-65. [CrossRef] [PubMed]

39. Ziegelbauer, J.M. Functions of Kaposi's sarcoma-associated herpesvirus microRNAs. Biochim. Biophys. Acta 2011, 1809, 623-630. [CrossRef] [PubMed]

40. Lee, Y.; Kim, M.; Han, J.; Yeom, K.-H.; Lee, S.; Baek, S.H.; Kim, V.N. MicroRNA genes are transcribed by RNA polymerase II. EMBO J. 2004, 23, 4051-4060. [CrossRef] [PubMed]

41. Lagos-Quintana, M.; Rauhut, R.; Lendeckel, W.; Tuschl, T. Identification of novel genes coding for small expressed RNAs. Science 2001, 294, 853-858. [CrossRef] [PubMed]

42. Lee, Y.; Ahn, C.; Han, J.; Choi, H.; Kim, J.; Yim, J.; Lee, J.; Provost, P.; Rådmark, O.; Kim, S.; et al. The nuclear RNase III Drosha initiates microRNA processing. Nature 2003, 425, 415-419. [CrossRef] [PubMed]

43. Lund, E.; Güttinger, S.; Calado, A.; Dahlberg, J.E.; Kutay, U. Nuclear export of microRNA precursors. Science 2004, 303, 95-98. [CrossRef] [PubMed]

44. Bohnsack, M.T.; Czaplinski, K.; Gorlich, D. Exportin 5 is a RanGTP-dependent dsRNA-binding protein that mediates nuclear export of pre-miRNAs. RNA 2004, 10, 185-191. [CrossRef] [PubMed]

45. Yi, R.; Qin, Y.; Macara, I.G.; Cullen, B.R. Exportin-5 mediates the nuclear export of pre-microRNAs and short hairpin RNAs. Genes Dev. 2003, 17, 3011-3016. [CrossRef] [PubMed]

46. Bernstein, E.; Caudy, A.A.; Hammond, S.M.; Hannon, G.J. Role for a bidentate ribonuclease in the initiation step of RNA interference. Nature 2001, 409, 363-366. [CrossRef] [PubMed]

47. Hutvágner, G.; McLachlan, J.; Pasquinelli, A.E.; Bálint, E.; Tuschl, T.; Zamore, P.D. A cellular function for the RNA-interference enzyme Dicer in the maturation of the let-7 small temporal RNA. Science 2001, 293, 834-838. [CrossRef] [PubMed]

48. Zamore, P.D.; Tuschl, T.; Sharp, P.A.; Bartel, D.P. RNAi: Double-stranded RNA directs the ATP-dependent cleavage of mRNA at 21 to 23 nucleotide intervals. Cell 2000, 101, 25-33. [CrossRef]

49. Chekulaeva, M.; Filipowicz, W. Mechanisms of miRNA-mediated post-transcriptional regulation in animal cells. Curr. Opin. Cell. Biol. 2009, 21, 452-460. [CrossRef] [PubMed]

50. Doench, J.G.; Sharp, P.A. Specificity of microRNA target selection in translational repression. Genes Dev. 2004, 18, 504-511. [CrossRef] [PubMed]

51. Brennecke, J.; Stark, A.; Russell, R.B.; Cohen, S.M. Principles of microRNA-target recognition. PLoS Biol. 2005, 3, 404-418. [CrossRef] [PubMed]

52. Larsson, O.; Nadon, R. Re-analysis of genome wide data on mammalian microRNA-mediated suppression of gene expression. Translation 2013, 1, e24557/1-e24557/9. [CrossRef] [PubMed]

53. Djuranovic, S.; Nahvi, A.; Green, R. miRNA-mediated gene silencing by translational repression followed by mRNA deadenylation and decay. Science 2012, 336, 237-240. [CrossRef] [PubMed]

54. Bazzini, A.A.; Lee, M.T.; Giraldez, A.J. Ribosome profiling shows that miR-430 reduces translation before causing mRNA decay in zebrafish. Science 2012, 336, 233-237. [CrossRef] [PubMed]

55. Béthune, J.; Artus-Revel, C.G.; Filipowicz, W. Kinetic analysis reveals successive steps leading to miRNA-mediated silencing in mammalian cells. EMBO Rep. 2012, 13, 716-723. [CrossRef] [PubMed]

56. Fabian, M.R.; Mathonnet, G.; Sundermeier, T.; Mathys, H.; Zipprich, J.T.; Svitkin, Y.V.; Rivas, F.; Jinek, M.; Wohlschlegel, J.; Doudna, J.A.; et al. Mammalian miRNA RISC Recruits CAF1 and PABP to Affect PABP-Dependent Deadenylation. Mol. Cell 2009, 35, 868-880. [CrossRef] [PubMed]

57. Guo, H.; Ingolia, N.T.; Weissman, J.S.; Bartel, D.P. Mammalian microRNAs predominantly act to decrease target mRNA levels. Nature 2010, 466, 835-840. [CrossRef] [PubMed]

58. Du, T.; Han, Z.; Zhou, G.; Roizman, B. Patterns of accumulation of miRNAs encoded by herpes simplex virus during productive infection, latency, and on reactivation. Proc. Natl. Acad. Sci. USA 2015, 112, E49-E55. [CrossRef] [PubMed] 
59. Wagner, E.K.; Devi-Rao, G.; Feldman, L.T.; Dobson, A.T.; Zhang, Y.F.; Flanagan, W.M.; Stevens, J.G. Physical characterization of the herpes simplex virus latency-associated transcript in neurons. J. Virol. 1988, 62, 1194-1202. [PubMed]

60. Randall, G.; Lagunoff, M.; Roizman, B. Herpes simplex virus 1 open reading frames $\mathrm{O}$ and $\mathrm{P}$ are not necessary for establishment of latent infection in mice. J. Virol. 2000, 74, 9019-9027. [CrossRef] [PubMed]

61. Cui, C.; Griffiths, A.; Li, G.; Silva, L.M.; Kramer, M.F.; Gaasterland, T.; Wang, X.-J.; Coen, D.M. Prediction and identification of herpes simplex virus 1-encoded microRNAs. J. Virol. 2006, 80, 5499-5508. [CrossRef] [PubMed]

62. Tang, S.; Patel, A.; Krause, P.R. Novel Less-Abundant Viral MicroRNAs Encoded by Herpes Simplex Virus 2 Latency-Associated Transcript and Their Roles in Regulating ICP34.5 and ICP0 mRNAs. J. Virol. 2009, 83, 1433-1442. [CrossRef] [PubMed]

63. Tang, S.; Bertke, A.S.; Patel, A.; Wang, K.; Cohen, J.I.; Krause, P.R. An acutely and latently expressed herpes simplex virus 2 viral microRNA inhibits expression of ICP34.5, a viral neurovirulence factor. Proc. Natl. Acad. Sci. USA 2008, 105, 10931-10936. [CrossRef] [PubMed]

64. Umbach, J.L.; Nagel, M.A.; Cohrs, R.J.; Gilden, D.H.; Cullen, B.R. Analysis of human alphaherpesvirus microRNA expression in latently infected human trigeminal ganglia. J. Virol. 2009, 83, 10677-10683. [CrossRef] [PubMed]

65. Umbach, J.L.; Wang, K.; Tang, S.; Krause, P.R.; Mont, E.K.; Cohen, J.I.; Cullen, B.R. Identification of viral microRNAs expressed in human sacral ganglia latently infected with herpes simplex virus 2. J. Virol. 2010, 84, 1189-1192. [CrossRef] [PubMed]

66. Jurak, I.; Kramer, M.F.; Mellor, J.C.; van Lint, A.L.; Roth, F.P.; Knipe, D.M.; Coen, D.M. Numerous conserved and divergent microRNAs expressed by herpes simplex viruses 1 and 2. J. Virol. 2010, 84, 4659-4672. [CrossRef] [PubMed]

67. Umbach, J.L.; Kramer, M.F.; Jurak, I.; Karnowski, H.W.; Coen, D.M.; Cullen, B.R. MicroRNAs expressed by herpes simplex virus 1 during latent infection regulate viral mRNAs. Nature 2008, 454, 780-783. [CrossRef] [PubMed]

68. Wu, W.; Guo, Z.; Zhang, X.; Guo, L.; Liu, L.; Liao, Y.; Wang, J.; Wang, L.; Li, Q. A microRNA encoded by HSV-1 inhibits a cellular transcriptional repressor of viral immediate early and early genes. Sci. China Life Sci. 2013, 56, 373-383. [CrossRef] [PubMed]

69. Munson, D.J.; Burch, A.D. A novel miRNA produced during lytic HSV-1 infection is important for efficient replication in tissue culture. Arch. Virol. 2012, 157, 1677-1688. [CrossRef] [PubMed]

70. Duan, F.; Liao, J.; Huang, Q.; Nie, Y.; Wu, K. HSV-1 miR-H6 Inhibits HSV-1 Replication and IL-6 Expression in Human Corneal Epithelial Cells In Vitro. Clin. Dev. Immunol. 2012, 2012, 1-8. [CrossRef] [PubMed]

71. Tang, S.; Bertke, A.S.; Patel, A.; Margolis, T.P.; Krause, P.R. Herpes simplex virus 2 microRNA miR-H6 is a novel latency-associated transcript-associated microRNA, but reduction of its expression does not influence the establishment of viral latency or the recurrence phenotype. J. Virol. 2011, 85, 4501-4509. [CrossRef] [PubMed]

72. Samaniego, L.A.; Wu, N.; DeLuca, N.A. The herpes simplex virus immediate-early protein ICP0 affects transcription from the viral genome and infected-cell survival in the absence of ICP4 and ICP27. J. Virol. 1997, 71, 4614-4625. [PubMed]

73. Zheng, S.; Li, Y.; Zhang, Y.; Li, X.; Tang, H. MiR-101 regulates HSV-1 replication by targeting ATP5B. Antivir. Res. 2011, 89, 219-226. [CrossRef] [PubMed]

74. Ru, J.; Sun, H.; Fan, H.; Wang, C.; Li, Y.; Liu, M.; Tang, H. MiR-23a facilitates the replication of HSV-1 through the suppression of interferon regulatory factor 1. PLoS ONE 2014, 9, e114021. [CrossRef] [PubMed]

75. Hill, J.M.; Zhao, Y.; Clement, C.; Neumann, D.M.; Lukiw, W.J. HSV-1 infection of human brain cells induces miRNA-146a and Alzheimer-type inflammatory signaling. NeuroReport 2009, 20, 1500-1505. [CrossRef] [PubMed]

76. Varani, S.; Landini, M. Cytomegalovirus-induced immunopathology and its clinical consequences. Herpesviridae 2011, 2, 6. [CrossRef] [PubMed]

77. Ng, K.R.; Li, J.Y.; Gleadle, J.M. Human cytomegalovirus encoded microRNAs: Hitting targets. Expert Rev. Anti-Infect. Ther. 2015, 13, 1469-1479. [CrossRef] [PubMed] 
78. Pfeffer, S.; Sewer, A.; Lagos-Quintana, M.; Sheridan, R.; Sander, C.; Grässer, F.A.; van Dyk, L.F.; Ho, C.K.; Shuman, S.; Chien, M.; et al. Identification of microRNAs of the herpesvirus family. Nat. Methods 2005, 2, 269-276. [CrossRef] [PubMed]

79. Grey, F.; Antoniewicz, A.; Allen, E.; Saugstad, J.; McShea, A.; Carrington, J.C.; Nelson, J. Identification and characterization of human cytomegalovirus-encoded microRNAs. J. Virol. 2005, 79, 12095-12099. [CrossRef] [PubMed]

80. Dunn, W.; Trang, P.; Zhong, Q.; Yang, E.; van Belle, C.; Liu, F. Human cytomegalovirus expresses novel microRNAs during productive viral infection. Cell. Microbiol. 2005, 7, 1684-1695. [CrossRef] [PubMed]

81. Stark, T.J.; Arnold, J.D.; Spector, D.H.; Yeo, G.W. High-resolution profiling and analysis of viral and host small RNAs during human cytomegalovirus infection. J. Virol. 2012, 86, 226-235. [CrossRef] [PubMed]

82. Stern-Ginossar, N.; Elefant, N.; Zimmermann, A.; Wolf, D.G.; Saleh, N.; Biton, M.; Horwitz, E.; Prokocimer, Z.; Prichard, M.; Hahn, G.; et al. Host immune system gene targeting by a viral miRNA. Science 2007, 317, 376-381. [CrossRef] [PubMed]

83. Nachmani, D.; Lankry, D.; Wolf, D.G.; Mandelboim, O. The human cytomegalovirus microRNA miR-UL112 acts synergistically with a cellular microRNA to escape immune elimination. Nat. Immunol. 2010, 11, 806-813. [CrossRef] [PubMed]

84. Huang, Y.; Qi, Y.; Ma, Y.; He, R.; Ji, Y.; Sun, Z.; Ruan, Q. The expression of interleukin-32 is activated by human cytomegalovirus infection and down regulated by hcmv-miR-UL112-1. J. Virol. 2013, 10, 51. [CrossRef] [PubMed]

85. Esteso, G.; Luzon, E.; Sarmiento, E.; Gomez-Caro, R.; Steinle, A.; Murphy, G.; Carbone, J.; Vales-Gomez, M.; Reyburn, H.T. Altered MicroRNA Expression after Infection with Human Cytomegalovirus Leads to TIMP3 Downregulation and Increased Shedding of Metalloprotease Substrates, Including MICA. J. Immunol. 2014, 193, 1344-1352. [CrossRef] [PubMed]

86. Kim, Y.; Lee, S.; Kim, S.; Kim, D.; Ahn, J.-H.; Ahn, K. Human cytomegalovirus clinical strain-specific microRNA miR-UL148D targets the human chemokine RANTES during infection. PLoS Pathog. 2012, 8, e1002577. [CrossRef] [PubMed]

87. Maghazachi, A.A.; Al-Aoukaty, A.; Schall, T.J. CC chemokines induce the generation of killer cells from CD56+ cells. Eur. J. Immunol. 1996, 26, 315-319. [CrossRef] [PubMed]

88. Landais, I.; Pelton, C.; Streblow, D.; DeFilippis, V.; McWeeney, S.; Nelson, J.A. Human Cytomegalovirus miR-UL112-3p Targets TLR2 and Modulates the TLR2/IRAK1/NFkB Signaling Pathway. PLoS Pathog. 2015, 11, e1004881. [CrossRef] [PubMed]

89. Kim, S.; Lee, S.; Shin, J.; Kim, Y.; Evnouchidou, I.; Kim, D.; Kim, Y.-K.; Kim, Y.-E.; Ahn, J.-H.; Riddell, S.R.; et al. Human cytomegalovirus microRNA miR-US4-1 inhibits CD8 ${ }^{+} \mathrm{T}$ cell responses by targeting the aminopeptidase ERAP1. Nat. Immunol. 2011, 12, 984-991. [CrossRef] [PubMed]

90. Noriega, V.; Redmann, V.; Gardner, T.; Tortorella, D. Diverse immune evasion strategies by human cytomegalovirus. Immunol. Res. 2012, 54, 140-151. [CrossRef] [PubMed]

91. Grey, F.; Meyers, H.; White, E.A.; Spector, D.H.; Nelson, J. A human cytomegalovirus-encoded microRNA regulates expression of multiple viral genes involved in replication. PLoS Pathog. 2007, 3, 1593-1602. [CrossRef] [PubMed]

92. Grey, F.; Tirabassi, R.; Meyers, H.; Wu, G.; McWeeney, S.; Hook, L.; Nelson, J.A. A viral microRNA down-regulates multiple cell cycle genes through mRNA 5'UTRs. PLoS Pathog. 2010, 6, e1000967. [CrossRef] [PubMed]

93. Qi, M.; Qi, Y.; Ma, Y.; He, R.; Ji, Y.; Sun, Z.; Ruan, Q. Over-expression of human cytomegalovirus miR-US25-2-3p downregulates eIF4A1 and inhibits HCMV replication. FEBS Lett. 2013, 587, 2266-2271. [CrossRef] [PubMed]

94. Pavelin, J.; Reynolds, N.; Chiweshe, S.; Wu, G.; Tiribassi, R.; Grey, F. Systematic MicroRNA Analysis Identifies ATP6V0C as an Essential Host Factor for Human Cytomegalovirus Replication. PLoS Pathog. 2013, 9, 1-13. [CrossRef] [PubMed]

95. Hook, L.M.; Grey, F.; Grabski, R.; Tirabassi, R.; Doyle, T.; Hancock, M.; Landais, I.; Jeng, S.; McWeeney, S.; Britt, W.; et al. Cytomegalovirus miRNAs Target Secretory Pathway Genes to Facilitate Formation of the Virion Assembly Compartment and Reduce Cytokine Secretion. Cell Host Microbe 2014, 15, 363-373. [CrossRef] [PubMed] 
96. Murphy, E.; Vanicek, J.; Robins, H.; Shenk, T.; Levine, A.J. Suppression of immediate-early viral gene expression by herpesvirus-coded microRNAs: Implications for latency. Proc. Natl. Acad. Sci. USA 2008, 105, 5453-5458. [CrossRef] [PubMed]

97. Stern-Ginossar, N.; Saleh, N.; Goldberg, M.D.; Prichard, M.; Wolf, D.G.; Mandelboim, O. Analysis of human cytomegalovirus-encoded microRNA activity during infection. J. Virol. 2009, 83, 10684-10693. [CrossRef] [PubMed]

98. Tirabassi, R.; Hook, L.; Landais, I.; Grey, F.; Meyers, H.; Hewitt, H.; Nelson, J. Human Cytomegalovirus US7 Is Regulated Synergistically by Two Virally Encoded MicroRNAs and by Two Distinct Mechanisms. J. Virol. 2011, 85, 11938-11944. [CrossRef] [PubMed]

99. Huang, Y.; Qi, Y.; Ma, Y.; He, R.; Ji, Y.; Sun, Z.; Ruan, Q. Down-regulation of human cytomegalovirus UL138, a novel latency-associated determinant, by homv-miR-UL36. J. Biosci. 2013, 38, 479-485. [CrossRef] [PubMed]

100. Meshesha, M.K.; Bentwich, Z.; Solomon, S.A.; Avni, Y.S. In vivo expression of human cytomegalovirus (HCMV) microRNAs during latency. Gene 2016, 575, 101-107. [CrossRef] [PubMed]

101. Fu, M.; Gao, Y.; Zhou, Q.; Zhang, Q.; Peng, Y.; Tian, K.; Wang, J.; Zheng, X. Human cytomegalovirus latent infection alters the expression of cellular and viral microRNA. Gene 2014, 536, 272-278. [CrossRef] [PubMed]

102. Fu, Y.-R.; Liu, X.-J.; Li, X.-J.; Shen, Z.-Z.; Yang, B.; Wu, C.-C.; Li, J.-F.; Miao, L.-F.; Ye, H.-Q.; Qiao, G.-H.; et al. miR-21 Attenuates Human Cytomegalovirus Replication in Neural Cells by Targeting Cdc25a. J. Virol. 2014, 89, 1070-1082. [CrossRef] [PubMed]

103. Luo, M.H.; Hannemann, H.; Kulkarni, A.S.; Schwartz, P.H.; O’Dowd, J.M.; Fortunato, E.A. Human Cytomegalovirus Infection Causes Premature and Abnormal Differentiation of Human Neural Progenitor Cells. J. Virol. 2010, 84, 3528-3541. [CrossRef] [PubMed]

104. Wang, F.; Weber, F.; Croce, C.; Liu, C.; Liao, X.; Pellett, P.E. Human cytomegalovirus infection alters the expression of cellular microRNA species that affect its replication. J. Virol. 2008, 82, 9065-9074. [CrossRef] [PubMed]

105. O'Connor, C.M.; Vanicek, J.; Murphy, E.A. Host miRNA regulation of human cytomegalovirus immediate early protein translation promotes viral latency. J. Virol. 2014, 88, 5524-5532.

106. Lisboa, L.F.; Egli, A.; O'Shea, D.; Åsberg, A.; Hartmann, A.; Rollag, H.; Pang, X.L.; Tyrrell, D.L.; Kumar, D.; Humar, A. Hcmv-miR-UL22A-5p: A Biomarker in Transplantation With Broad Impact on Host Gene Expression and Potential Immunological Implications. Am. J. Transpl. 2015, 15, 1893-1902. [CrossRef] [PubMed]

107. Thi, E.P.; Mire, C.E.; Lee, A.C.H.; Geisbert, J.B.; Zhou, J.Z.; Agans, K.N.; Snead, N.M.; Deer, D.J.; Barnard, T.R.; Fenton, K.A.; et al. Lipid nanoparticle siRNA treatment of Ebola-virus-Makona-infected nonhuman primates. Nature 2015, 521, 362-365. [CrossRef] [PubMed]

108. Janssen, H.L.A.A.; Reesink, H.W.; Lawitz, E.J.; Zeuzem, S.; Rodriguez-Torres, M.; Patel, K.; van der Meer, A.J.; Patick, A.K.; Chen, A.; Zhou, Y.; et al. Treatment of HCV Infection by Targeting MicroRNA. N. Engl. J. Med. 2013, 368, 1685-1694. [CrossRef] [PubMed]

109. Thorley-Lawson, D.A.; Hawkins, J.B.; Tracy, S.I.; Shapiro, M. The pathogenesis of Epstein-Barr virus persistent infection. Curr. Opin. Virol. 2013, 3, 227-232. [CrossRef] [PubMed]

110. Delecluse, H.-J.; Feederle, R.; O'Sullivan, B.; Taniere, P. Epstein Barr virus-associated tumours: An update for the attention of the working pathologist. J. Clin. Pathol. 2007, 60, 1358-1364. [CrossRef] [PubMed]

111. Murata, T.; Sato, Y.; Kimura, H. Modes of infection and oncogenesis by the Epstein-Barr virus. Rev. Med. Virol. 2014, 24, 242-253. [CrossRef] [PubMed]

112. Pratt, Z.L.; Kuzembayeva, M.; Sengupta, S.; Sugden, B. The microRNAs of Epstein-Barr Virus are expressed at dramatically differing levels among cell lines. Virology 2009, 386, 387-397. [CrossRef] [PubMed]

113. Cai, X.; Schäfer, A.; Lu, S.; Bilello, J.P.; Desrosiers, R.C.; Edwards, R.; Raab-Traub, N.; Cullen, B.R. Epstein-Barr virus microRNAs are evolutionarily conserved and differentially expressed. PLoS Pathog. 2006, 2, e23. [CrossRef] [PubMed]

114. Cosmopoulos, K.; Pegtel, M.; Hawkins, J.; Moffett, H.; Novina, C.; Middeldorp, J.; Thorley-Lawson, D.A. Comprehensive profiling of Epstein-Barr virus microRNAs in nasopharyngeal carcinoma. J. Virol. 2009, 83, 2357-2367. [CrossRef] [PubMed]

115. Grundhoff, A. A combined computational and microarray-based approach identifies novel microRNAs encoded by human gamma-herpesviruses. RNA 2006, 12, 733-750. [CrossRef] [PubMed] 
116. Landgraf, P.; Rusu, M.; Sheridan, R.; Sewer, A.; Iovino, N.; Aravin, A.; Pfeffer, S.; Rice, A.; Kamphorst, A.O.; Landthaler, M.; et al. A mammalian microRNA expression atlas based on small RNA library sequencing. Cell 2007, 129, 1401-1414. [CrossRef] [PubMed]

117. Lung, R.W.-M.; Tong, J.H.-M.; Sung, Y.-M.; Leung, P.-S.; Ng, D.C.-H.; Chau, S.-L.; Chan, A.W.-H.; Ng, E.K.-O.; Lo, K.-W.; To, K.-F. Modulation of LMP2A Expression by a Newly Identified Epstein-Barr Virus-Encoded MicroRNA miR-BART22. Neoplasia 2009, 11, 1174-IN17. [CrossRef] [PubMed]

118. Pfeffer, S.; Zavolan, M.; Grässer, F.A.; Chien, M.; Russo, J.J.; Ju, J.; John, B.; Enright, A.J.; Marks, D.; Sander, C.; et al. Identification of virus-encoded microRNAs. Science 2004, 304, 734-736. [CrossRef] [PubMed]

119. Zhu, J.Y.; Pfuhl, T.; Motsch, N.; Barth, S.; Nicholls, J.; Grasser, F.; Meister, G. Identification of Novel Epstein-Barr Virus MicroRNA Genes from Nasopharyngeal Carcinomas. J. Virol. 2009, 83, 3333-3341. [CrossRef] [PubMed]

120. Lo, A.K.F.; To, K.F.; Lo, K.W.; Lung, R.W.M.; Hui, J.W.Y.; Liao, G.; Hayward, S.D. Modulation of LMP1 protein expression by EBV-encoded microRNAs. Proc. Natl. Acad. Sci. USA 2007, 104, 16164-16169. [CrossRef] [PubMed]

121. Xia, T.; O’Hara, A.; Araujo, I.; Barreto, J.; Carvalho, E.; Sapucaia, J.B.; Ramos, J.C.; Luz, E.; Pedroso, C.; Manrique, M.; et al. EBV microRNAs in primary lymphomas and targeting of CXCL-11 by ebv-mir-BHRF1-3. Cancer Res. 2008, 68, 1436-1442. [CrossRef] [PubMed]

122. Marquitz, A.R.; Mathur, A.; Nam, C.S.; Raab-Traub, N. The Epstein-Barr Virus BART microRNAs target the pro-apoptotic protein Bim. Virology 2011, 412, 392-400. [CrossRef] [PubMed]

123. Vereide, D.T.; Seto, E.; Chiu, Y.-F.; Hayes, M.; Tagawa, T.; Grundhoff, A.; Hammerschmidt, W.; Sugden, B. Epstein-Barr virus maintains lymphomas via its miRNAs. Oncogene 2014, 33, 1258-1264. [CrossRef] [PubMed]

124. Nachmani, D.; Stern-Ginossar, N.; Sarid, R.; Mandelboim, O. Diverse herpesvirus microRNAs target the stress-induced immune ligand MICB to escape recognition by natural killer cells. Cell Host Microbe 2009, 5, 376-385. [CrossRef] [PubMed]

125. Lei, T.; Yuen, K.-S.; Xu, R.; Tsao, S.W.; Chen, H.; Li, M.; Kok, K.-H.; Jin, D.-Y. Targeting of DICE1 tumor suppressor by Epstein-Barr virus-encoded miR-BART3* microRNA in nasopharyngeal carcinoma. Int. J. Cancer 2013, 133, 79-87. [CrossRef] [PubMed]

126. Choy, E.Y.-W.; Siu, K.-L.; Kok, K.-H.; Lung, R.W.-M.; Tsang, C.M.; To, K.-F.; Kwong, D.L.-W.; Tsao, S.W.; Jin, D.-Y. An Epstein-Barr virus-encoded microRNA targets PUMA to promote host cell survival. J. Exp. Med. 2008, 205, 2551-2560. [CrossRef] [PubMed]

127. Godshalk, S.; Bhaduri-McIntosh, S.; Slack, F.J. Epstein-Barr virus-mediated dysregulation of human microRNA expression. Cell Cycle 2008, 7, 3595-3600. [CrossRef] [PubMed]

128. Iizasa, H.; Wulff, B.-E.; Alla, N.R.; Maragkakis, M.; Megraw, M.; Hatzigeorgiou, A.; Iwakiri, D.; Takada, K.; Wiedmer, A.; Showe, L.; et al. Editing of Epstein-Barr virus-encoded BART6 microRNAs controls their dicer targeting and consequently affects viral latency. J. Biol. Chem. 2010, 285, 33358-33370. [CrossRef] [PubMed]

129. Wong, A.M.G.; Kong, K.L.; Tsang, J.W.H.; Kwong, D.L.W.; Guan, X.-Y. Profiling of Epstein-Barr virus-encoded microRNAs in nasopharyngeal carcinoma reveals potential biomarkers and oncomirs. Cancer 2012, 118, 698-710. [CrossRef] [PubMed]

130. Haneklaus, M.; Gerlic, M.; Kurowska-Stolarska, M.; Rainey, A.-A.; Pich, D.; McInnes, I.B.; Hammerschmidt, W.; O'Neill, L.A.J.; Masters, S.L. Cutting Edge: miR-223 and EBV miR-BART15 Regulate the NLRP3 Inflammasome and IL-1 Production. J. Immunol. 2012, 189, 3795-3799. [CrossRef] [PubMed]

131. Kim, H.; Choi, H.; Lee, S.K. Epstein-Barr virus miR-BART20-5p regulates cell proliferation and apoptosis by targeting BAD. Cancer Lett. 2015, 356, 733-742. [CrossRef] [PubMed]

132. Mansouri, S.; Pan, Q.; Blencowe, B.J.; Claycomb, J.M.; Frappier, L. Epstein-Barr virus EBNA1 protein regulates viral latency through effects on let-7 microRNA and dicer. J. Virol. 2014, 88, 11166-11177. [CrossRef] [PubMed]

133. Ellis-Connell, A.L.; Iempridee, T.; Xu, I.; Mertz, J.E. Cellular microRNAs 200b and 429 regulate the Epstein-Barr virus switch between latency and lytic replication. J. Virol. 2010, 84, 10329-10343. [CrossRef] [PubMed]

134. Lin, Z.; Wang, X.; Fewell, C.; Cameron, J.; Yin, Q.; Flemington, E.K. Differential expression of the miR-200 family microRNAs in epithelial and B cells and regulation of Epstein-Barr virus reactivation by the miR-200 family member miR-429. J. Virol. 2010, 84, 7892-7897. [CrossRef] [PubMed] 
135. Klinke, O.; Feederle, R.; Delecluse, H.J. Genetics of Epstein-Barr virus microRNAs. Semin. Cancer Biol. 2014, 26, 52-59. [CrossRef] [PubMed]

136. Kraus, R.J.; Perrigoue, J.G.; Mertz, J.E. ZEB negatively regulates the lytic-switch BZLF1 gene promoter of Epstein-Barr virus. J. Virol. 2003, 77, 199-207. [CrossRef] [PubMed]

137. Ellis, A.L.; Wang, Z.; Yu, X.; Mertz, J.E. Either ZEB1 or ZEB2/SIP1 can play a central role in regulating the Epstein-Barr virus latent-lytic switch in a cell-type-specific manner. J. Virol. 2010, 84, 6139-6152. [CrossRef] [PubMed]

138. Gatto, G.; Rossi, A.; Rossi, D.; Kroening, S.; Bonatti, S.; Mallardo, M. Epstein-Barr virus latent membrane protein 1 trans-activates miR-155 transcription through the NF-kB pathway. Nucleic Acids Res. 2008, 36, 6608-6619. [CrossRef] [PubMed]

139. Cameron, J.E.; Fewell, C.; Yin, Q.; McBride, J.; Wang, X.; Lin, Z.; Flemington, E.K. Epstein-Barr virus growth/latency III program alters cellular microRNA expression. Virology 2008, 382, 257-266. [CrossRef] [PubMed]

140. Linnstaedt, S.D.; Gottwein, E.; Skalsky, R.L.; Luftig, M.A.; Cullen, B.R. Virally induced cellular microRNA miR-155 plays a key role in B-cell immortalization by Epstein-Barr virus. J. Virol. 2010, 84, 11670-11678. [CrossRef] [PubMed]

141. Chen, S.-J.; Chen, G.-H.; Chen, Y.-H.; Liu, C.-Y.; Chang, K.-P.; Chang, Y.-S.; Chen, H.-C. Characterization of Epstein-Barr virus miRNAome in nasopharyngeal carcinoma by deep sequencing. PLoS ONE 2010, 5, e12745. [CrossRef] [PubMed]

142. Kim, D.N.; Chae, H.-S.; Oh, S.T.; Kang, J.-H.; Park, C.H.; Park, W.S.; Takada, K.; Lee, J.M.; Lee, W.-K.; Lee, S.K. Expression of viral microRNAs in Epstein-Barr virus-associated gastric carcinoma. J. Virol. 2007, 81, 1033-1036. [CrossRef] [PubMed]

143. Marquitz, A.R.; Mathur, A.; Chugh, P.E.; Dittmer, D.P.; Raab-Traub, N. Expression profile of microRNAs in Epstein-Barr virus-infected AGS gastric carcinoma cells. J. Virol. 2014, 88, 1389-1393. [CrossRef] [PubMed]

144. Imig, J.; Motsch, N.; Zhu, J.Y.; Barth, S.; Okoniewski, M.; Reineke, T.; Tinguely, M.; Faggioni, A.; Trivedi, P.; Meister, G.; et al. microRNA profiling in Epstein-Barr virus-associated B-cell lymphoma. Nucleic Acids Res. 2011, 39, 1880-1893. [CrossRef] [PubMed]

145. Amoroso, R.; Fitzsimmons, L.; Thomas, W.A.; Kelly, G.L.; Rowe, M.; Bell, A.I. Quantitative studies of Epstein-Barr virus-encoded microRNAs provide novel insights into their regulation. J. Virol. 2011, 85, 996-1010. [CrossRef] [PubMed]

146. Motsch, N.; Alles, J.; Imig, J.; Zhu, J.; Barth, S.; Reineke, T.; Tinguely, M.; Cogliatti, S.; Dueck, A.; Meister, G.; et al. MicroRNA profiling of Epstein-Barr virus-associated NK/T-cell lymphomas by deep sequencing. PLOS ONE 2012, 7, e42193. [CrossRef] [PubMed]

147. Cai, L.-M.; Lyu, X.-M.; Luo, W.-R.; Cui, X.-F.; Ye, Y.-F.; Yuan, C.-C.; Peng, Q.-X.; Wu, D.-H.; Liu, T.-F.; Wang, E.; et al. EBV-miR-BART7-3p promotes the EMT and metastasis of nasopharyngeal carcinoma cells by suppressing the tumor suppressor PTEN. Oncogene 2015, 34, 2156-2166. [CrossRef] [PubMed]

148. Cai, L.; Ye, Y.; Jiang, Q.; Chen, Y.; Lyu, X.; Li, J.; Wang, S.; Liu, T.; Cai, H.; Yao, K.; et al. Epstein-Barr virus-encoded microRNA BART1 induces tumour metastasis by regulating PTEN-dependent pathways in nasopharyngeal carcinoma. Nat. Commun. 2015, 6, 7353. [CrossRef] [PubMed]

149. Kanda, T.; Miyata, M.; Kano, M.; Kondo, S.; Yoshizaki, T.; Iizasa, H. Clustered microRNAs of the Epstein-Barr virus cooperatively downregulate an epithelial cell-specific metastasis suppressor. J. Virol. 2015, 89, 2684-2697. [CrossRef] [PubMed]

150. Pegtel, D.M.; Cosmopoulos, K.; Thorley-Lawson, D.A.; van Eijndhoven, M.A.J.; Hopmans, E.S.; Lindenberg, J.L.; de Gruijl, T.D.; Wurdinger, T.; Middeldorp, J.M. Functional delivery of viral miRNAs via exosomes. Proc. Natl. Acad. Sci. USA 2010, 107, 6328-6333. [CrossRef] [PubMed]

151. Meckes, D.G.; Shair, K.H.Y.; Marquitz, A.R.; Kung, C.-P.; Edwards, R.H.; Raab-Traub, N. Human tumor virus utilizes exosomes for intercellular communication. Proc. Natl. Acad. Sci. USA 2010, 107, 20370-20375. [CrossRef] [PubMed]

152. Gourzones, C.; Gelin, A.; Bombik, I.; Klibi, J.; Vérillaud, B.; Guigay, J.; Lang, P.; Témam, S.; Schneider, V.; Amiel, C.; et al. Extra-cellular release and blood diffusion of BART viral micro-RNAs produced by EBV-infected nasopharyngeal carcinoma cells. J. Virol. 2010, 7, 271. [CrossRef] [PubMed]

153. Ascherio, A.; Munger, K.L. Epstein-Barr Virus Infection and Multiple Sclerosis: A Review. J. Neuroimmune Pharmacol. 2010, 5, 271-277. [CrossRef] [PubMed] 
154. Handel, A.E.; Williamson, A.J.; Disanto, G.; Handunnetthi, L.; Giovannoni, G.; Ramagopalan, S.V. An updated meta-analysis of risk of multiple sclerosis following infectious mononucleosis. PLoS ONE 2010, 5, 1-5. [CrossRef] [PubMed]

155. Levin, L.I.; Munger, K.L.; O’Reilly, E.J.; Falk, K.I.; Ascherio, A. Primary infection with the Epstein-Barr virus and risk of multiple sclerosis. Ann. Neurol. 2010, 67, 824-830. [CrossRef] [PubMed]

156. Pohl, D. Epstein-Barr virus and multiple sclerosis. J. Neurol. Sci. 2009, 286, 62-64. [CrossRef] [PubMed]

157. Thacker, E.L.; Mirzaei, F.; Ascherio, A. Infectious mononucleosis and risk for multiple sclerosis: A meta-analysis. Ann. Neurol. 2006, 59, 499-503. [CrossRef] [PubMed]

158. Qin, Z.; Jakymiw, A.; Findlay, V.; Parsons, C. KSHV-Encoded MicroRNAs: Lessons for Viral Cancer Pathogenesis and Emerging Concepts. Int. J. Cell Biol. 2012, 2012, 1-9. [CrossRef] [PubMed]

159. Cai, X.; Lu, S.; Zhang, Z.; Gonzalez, C.M.; Damania, B.; Cullen, B.R. Kaposi's sarcoma-associated herpesvirus expresses an array of viral microRNAs in latently infected cells. Proc. Natl. Acad. Sci. USA 2005, 102, 5570-5575. [CrossRef] [PubMed]

160. Samols, M.A.; Hu, J.; Skalsky, R.L.; Renne, R. Cloning and identification of a microRNA cluster within the latency-associated region of Kaposi's sarcoma-associated herpesvirus. J. Virol. 2005, 79, 9301-9305. [CrossRef] [PubMed]

161. Marshall, V.; Parks, T.; Bagni, R.; Wang, C.D.; Samols, M.A.; Hu, J.; Wyvil, K.M.; Aleman, K.; Little, R.F.; Yarchoan, R.; et al. Conservation of virally encoded microRNAs in Kaposi sarcoma-associated herpesvirus in primary effusion lymphoma cell lines and in patients with Kaposi sarcoma or multicentric Castleman disease. J. Infect. Dis 2007, 195, 645-659. [PubMed]

162. Umbach, J.L.; Cullen, B.R. In-depth analysis of Kaposi's sarcoma-associated herpesvirus microRNA expression provides insights into the mammalian microRNA-processing machinery. J. Virol. 2010, 84, 695-703. [CrossRef] [PubMed]

163. Marshall, V.; Martró, E.; Labo, N.; Ray, A.; Wang, D.; Mbisa, G.; Bagni, R.K.; Volfovsky, N.; Casabona, J.; Whitby, D. Kaposi sarcoma (KS)-associated herpesvirus microRNA sequence analysis and KS risk in a European AIDS-KS case control study. J. Infect. Dis 2010, 202, 1126-1135. [CrossRef] [PubMed]

164. Gottwein, E.; Cullen, B.R. A human herpesvirus microRNA inhibits p21 expression and attenuates p21-mediated cell cycle arrest. J. Virol. 2010, 84, 5229-5237. [CrossRef] [PubMed]

165. Lei, X.; Bai, Z.; Ye, F.; Xie, J.; Kim, C.-G.; Huang, Y.; Gao, S.-J. Regulation of NF-kB inhibitor IkB $\alpha$ and viral replication by a KSHV microRNA. Nat. Cell. Biol. 2010, 12, 193-199. [CrossRef] [PubMed]

166. Lei, X.; Zhu, Y.; Jones, T.; Bai, Z.; Huang, Y.; Gao, S.-J. A Kaposi's sarcoma-associated herpesvirus microRNA and its variants target the transforming growth factor $\beta$ pathway to promote cell survival. J. Virol. 2012, 86, 11698-11711. [CrossRef] [PubMed]

167. Suffert, G.; Malterer, G.; Hausser, J.; Viiliäinen, J.; Fender, A.; Contrant, M.; Ivacevic, T.; Benes, V.; Gros, F.; Voinnet, O.; et al. Kaposi's sarcoma herpesvirus microRNAs target caspase 3 and regulate apoptosis. PLoS Pathog. 2011, 7, e1002405. [CrossRef] [PubMed]

168. Qin, Z.; Freitas, E.; Sullivan, R.; Mohan, S.; Bacelieri, R.; Branch, D.; Romano, M.; Kearney, P.; Oates, J.; Plaisance, K.; et al. Upregulation of xCT by KSHV-encoded microRNAs facilitates KSHV dissemination and persistence in an environment of oxidative stress. PLoS Pathog. 2010, 6, e1000742. [CrossRef] [PubMed]

169. Hansen, A.; Henderson, S.; Lagos, D.; Nikitenko, L.; Coulter, E.; Roberts, S.; Gratrix, F.; Plaisance, K.; Renne, R.; Bower, M.; et al. KSHV-encoded miRNAs target MAF to induce endothelial cell reprogramming. Genes Dev. 2010, 24, 195-205. [CrossRef] [PubMed]

170. Skalsky, R.L.; Samols, M.A.; Plaisance, K.B.; Boss, I.W.; Riva, A.; Lopez, M.C.; Baker, H.V.; Renne, R. Kaposi's sarcoma-associated herpesvirus encodes an ortholog of miR-155. J. Virol. 2007, 81, 12836-12845. [CrossRef] [PubMed]

171. Gottwein, E.; Mukherjee, N.; Sachse, C.; Frenzel, C.; Majoros, W.H.; Chi, J.-T.A.; Braich, R.; Manoharan, M.; Soutschek, J.; Ohler, U.; et al. A viral microRNA functions as an orthologue of cellular miR-155. Nature 2007, 450, 1096-1099. [CrossRef] [PubMed]

172. Lu, C.-C.; Li, Z.; Chu, C.-Y.; Feng, J.; Feng, J.; Sun, R.; Rana, T.M. MicroRNAs encoded by Kaposi's sarcoma-associated herpesvirus regulate viral life cycle. EMBO Rep. 2010, 11, 784-790. [CrossRef] [PubMed]

173. Lu, F.; Stedman, W.; Yousef, M.; Renne, R.; Lieberman, P.M. Epigenetic regulation of Kaposi's sarcoma-associated herpesvirus latency by virus-encoded microRNAs that target Rta and the cellular Rbl2-DNMT pathway. J. Virol. 2010, 84, 2697-2706. [CrossRef] [PubMed] 
174. Ziegelbauer, J.M.; Sullivan, C.S.; Ganem, D. Tandem array-based expression screens identify host mRNA targets of virus-encoded microRNAs. Nat. Genet. 2009, 41, 130-134. [CrossRef] [PubMed]

175. Abend, J.R.; Ramalingam, D.; Kieffer-Kwon, P.; Uldrick, T.S.; Yarchoan, R.; Ziegelbauer, J.M. Kaposi's sarcoma-associated herpesvirus microRNAs target IRAK1 and MYD88, two components of the toll-like receptor/interleukin-1R signaling cascade, to reduce inflammatory-cytokine expression. J. Virol. 2012, 86, 11663-11674. [CrossRef] [PubMed]

176. Lin, X.; Liang, D.; He, Z.; Deng, Q.; Robertson, E.S.; Lan, K. miR-K12-7-5p encoded by Kaposi's sarcoma-associated herpesvirus stabilizes the latent state by targeting viral ORF50/RTA. PLoS ONE 2011, 6, e16224. [CrossRef] [PubMed]

177. Bellare, P.; Ganem, D. Regulation of KSHV Lytic Switch Protein Expression by a Virus-Encoded MicroRNA: An Evolutionary Adaptation that Fine-Tunes Lytic Reactivation. Cell Host Microbe 2009, 6, 570-575. [CrossRef] [PubMed]

178. Abend, J.R.; Uldrick, T.; Ziegelbauer, J.M. Regulation of tumor necrosis factor-like weak inducer of apoptosis receptor protein (TWEAKR) expression by Kaposi's sarcoma-associated herpesvirus microRNA prevents TWEAK-induced apoptosis and inflammatory cytokine expression. J. Virol. 2010, 84, 12139-12151. [CrossRef] [PubMed]

179. Liang, D.; Gao, Y.; Lin, X.; He, Z.; Zhao, Q.; Deng, Q.; Lan, K. A human herpesvirus miRNA attenuates interferon signaling and contributes to maintenance of viral latency by targeting IKKe. Cell Res. 2011, 21, 793-806. [CrossRef] [PubMed]

180. Boss, I.W.; Nadeau, P.E.; Abbott, J.R.; Yang, Y.; Mergia, A.; Renne, R. A Kaposi's sarcoma-associated herpesvirus-encoded ortholog of microRNA miR-155 induces human splenic B-cell expansion in NOD/LtSz-scid IL2R $\gamma$ null mice. J. Virol. 2011, 85, 9877-9886. [CrossRef] [PubMed]

181. Liu, Y.; Sun, R.; Lin, X.; Liang, D.; Deng, Q.; Lan, K. Kaposi's sarcoma-associated herpesvirus-encoded microRNA miR-K12-11 attenuates transforming growth factor beta signaling through suppression of SMAD5. J. Virol. 2012, 86, 1372-1381. [CrossRef] [PubMed]

182. Moody, R.; Zhu, Y.; Huang, Y.; Cui, X.; Jones, T.; Bedolla, R.; Lei, X.; Bai, Z.; Gao, S.-J. KSHV microRNAs mediate cellular transformation and tumorigenesis by redundantly targeting cell growth and survival pathways. PLoS Pathog. 2013, 9, e1003857. [CrossRef] [PubMed]

183. Gottwein, E.; Corcoran, D.L.; Mukherjee, N.; Skalsky, R.L.; Hafner, M.; Nusbaum, J.D.; Shamulailatpam, P.; Love, C.L.; Dave, S.S.; Tuschl, T.; et al. Viral MicroRNA Targetome of KSHV-Infected Primary Effusion Lymphoma Cell Lines. Cell Host Microbe 2011, 10, 515-526. [CrossRef] [PubMed]

184. Manzano, M.; Shamulailatpam, P.; Raja, A.N.; Gottwein, E. Kaposi's sarcoma-associated herpesvirus encodes a mimic of cellular miR-23. J. Virol. 2013, 87, 11821-11830. [CrossRef] [PubMed]

185. Mashima, R. Physiological roles of miR-155. Immunology 2015, 145, 323-333. [CrossRef] [PubMed]

186. Qin, Z.; Peruzzi, F.; Reiss, K.; Dai, L. Role of host microRNAs in Kaposi's sarcoma-associated herpesvirus pathogenesis. Viruses 2014, 6, 4571-4580. [CrossRef] [PubMed]

187. Tsai, Y.-H.; Wu, M.-F.; Wu, Y.-H.; Chang, S.-J.; Lin, S.-F.; Sharp, T.V.; Wang, H.-W. The M type K15 protein of Kaposi's sarcoma-associated herpesvirus regulates microRNA expression via its SH2-binding motif to induce cell migration and invasion. J. Virol. 2009, 83, 622-632. [CrossRef] [PubMed]

188. Wu, Y.-H.; Hu, T.-F.; Chen, Y.-C.; Tsai, Y.-N.; Tsai, Y.-H.; Cheng, C.-C.; Wang, H.-W. The manipulation of miRNA-gene regulatory networks by KSHV induces endothelial cell motility. Blood 2011, 118, 2896-2905. [CrossRef] [PubMed]

189. Bridge, G.; Monteiro, R.; Henderson, S.; Emuss, V.; Lagos, D.; Georgopoulou, D.; Patient, R.; Boshoff, C. The microRNA-30 family targets DLL4 to modulate endothelial cell behavior during angiogenesis. Blood 2012, 120, 5063-5072. [CrossRef] [PubMed]

190. Punj, V.; Matta, H.; Schamus, S.; Tamewitz, A.; Anyang, B.; Chaudhary, P.M. Kaposi's sarcoma-associated herpesvirus-encoded viral FLICE inhibitory protein (vFLIP) K13 suppresses CXCR4 expression by upregulating miR-146a. Oncogene 2010, 29, 1835-1844. [CrossRef] [PubMed]

191. Kang, J.-G.; Majerciak, V.; Uldrick, T.S.; Wang, X.; Kruhlak, M.; Yarchoan, R.; Zheng, Z.-M. Kaposi's sarcoma-associated herpesviral IL-6 and human IL-6 open reading frames contain miRNA binding sites and are subject to cellular miRNA regulation. J. Pathol. 2011, 225, 378-389. [CrossRef] [PubMed]

192. Kang, J.-G.; Pripuzova, N.; Majerciak, V.; Kruhlak, M.; Le, S.-Y.; Zheng, Z.-M. Kaposi's sarcoma-associated herpesvirus ORF57 promotes escape of viral and human interleukin-6 from microRNA-mediated suppression. J. Virol. 2011, 85, 2620-2630. [CrossRef] [PubMed] 
193. Lagos, D.; Pollara, G.; Henderson, S.; Gratrix, F.; Fabani, M.; Milne, R.S.B.; Gotch, F.; Boshoff, C. miR-132 regulates antiviral innate immunity through suppression of the p300 transcriptional co-activator. Nat. Cell Biol. 2010, 12, 513-519. [CrossRef] [PubMed]

194. Yan, Q.; Ma, X.; Shen, C.; Cao, X.; Feng, N.; Qin, D.; Zeng, Y.; Zhu, J.; Gao, S.-J.; Lu, C. Inhibition of Kaposi's sarcoma-associated herpesvirus lytic replication by HIV-1 Nef and cellular microRNA hsa-miR-1258. J. Virol. 2014, 88, 4987-5000. [CrossRef] [PubMed]

195. Yan, Q.; Li, W.; Tang, Q.; Yao, S.; Lv, Z.; Feng, N.; Ma, X.; Bai, Z.; Zeng, Y.; Qin, D.; et al. Cellular microRNAs 498 and 320d regulate herpes simplex virus 1 induction of Kaposi's sarcoma-associated herpesvirus lytic replication by targeting RTA. PLoS ONE 2013, 8, e55832. [CrossRef] [PubMed]

196. Shin, C.; Nam, J.-W.; Farh, K.K.-H.; Chiang, H.R.; Shkumatava, A.; Bartel, D.P. Expanding the microRNA targeting code: functional sites with centered pairing. Mol. Cell 2010, 38, 789-802. [CrossRef] [PubMed]

197. Lim, L.P.; Lau, N.C.; Garrett-Engele, P.; Grimson, A.; Schelter, J.M.; Castle, J.; Bartel, D.P.; Linsley, P.S.; Johnson, J.M. Microarray analysis shows that some microRNAs downregulate large numbers of target mRNAs. Nature 2005, 433, 769-773. [CrossRef] [PubMed]

198. Dölken, L.; Malterer, G.; Erhard, F.; Kothe, S.; Friedel, C.C.; Suffert, G.; Marcinowski, L.; Motsch, N.; Barth, S.; Beitzinger, M.; et al. Systematic Analysis of Viral and Cellular MicroRNA Targets in Cells Latently Infected with Human $\gamma$-Herpesviruses by RISC Immunoprecipitation Assay. Cell Host Microbe 2010, 7, 324-334. [CrossRef] [PubMed]

199. Haecker, I.; Gay, L.A.; Yang, Y.; Hu, J.; Morse, A.M.; McIntyre, L.M.; Renne, R. Ago HITS-CLIP Expands Understanding of Kaposi's Sarcoma-associated Herpesvirus miRNA Function in Primary Effusion Lymphomas. PLoS Pathog. 2012, 8, e1002884. [CrossRef] [PubMed]

200. Riley, K.J.; Rabinowitz, G.S.; Yario, T.A.; Luna, J.M.; Darnell, R.B.; Steitz, J.A. EBV and human microRNAs co-target oncogenic and apoptotic viral and human genes during latency. EMBO J. 2012, 31, 2207-2221. [CrossRef] [PubMed]

201. Skalsky, R.L.; Corcoran, D.L.; Gottwein, E.; Frank, C.L.; Kang, D.; Hafner, M.; Nusbaum, J.D.; Feederle, R.; Delecluse, H.J.; Luftig, M.A.; et al. The viral and cellular microRNA targetome in lymphoblastoid cell lines. PLoS Pathog. 2012, 8. [CrossRef] [PubMed]

202. Gallaher, A.M.; Das, S.; Xiao, Z.; Andresson, T.; Kieffer-Kwon, P.; Happel, C.; Ziegelbauer, J. Proteomic Screening of Human Targets of Viral microRNAs Reveals Functions Associated with Immune Evasion and Angiogenesis. PLoS Pathog. 2013, 9, e1002484. [CrossRef] [PubMed]

203. Lee, S.H.; Kalejta, R.F.; Kerry, J.; Semmes, O.J.; O'Connor, C.M.; Khan, Z.; Garcia, B.A.; Shenk, T.; Murphy, E. $\mathrm{BclAF} 1$ restriction factor is neutralized by proteasomal degradation and microRNA repression during human cytomegalovirus infection. Proc. Natl. Acad. Sci. USA 2012, 109, 9575-9580. [CrossRef] [PubMed]

204. Grosswendt, S.; Filipchyk, A.; Manzano, M.; Klironomos, F.; Schilling, M.; Herzog, M.; Gottwein, E.; Rajewsky, N. Unambiguous Identification of miRNA: Target site interactions by different types of ligation reactions. Mol. Cell 2014, 54, 1042-1054. [CrossRef] [PubMed]

205. Helwak, A.; Tollervey, D. Mapping the miRNA interactome by cross-linking ligation and sequencing of hybrids (CLASH). Nat. Protoc. 2014, 9, 711-728. [CrossRef] [PubMed]

206. Feldman, E.R.; Kara, M.; Coleman, C.B.; Grau, K.R.; Oko, L.M.; Krueger, B.J.; Renne, R.; van Dyk, L.F.; Tibbetts, S.A. Virus-encoded microRNAs facilitate gammaherpesvirus latency and pathogenesis in vivo. MBio 2014, 5, e00981-14. [CrossRef] [PubMed]

207. Yu, Z.H.; Teng, M.; Sun, A.J.; Yu, L.L.; Hu, B.; Qu, L.H.; Ding, K.; Cheng, X.C.; Liu, J.X.; Cui, Z.Z.; et al. Virus-encoded miR-155 ortholog is an important potential regulator but not essential for the development of lymphomas induced by very virulent Marek's disease virus. Virology 2014, 448, 55-64. [CrossRef] [PubMed]

208. Kramer, M.F.; Jurak, I.; Pesola, J.M.; Boissel, S.; Knipe, D.M.; Coen, D.M. Herpes simplex virus 1 microRNAs expressed abundantly during latent infection are not essential for latency in mouse trigeminal ganglia. Virology 2011, 417, 239-247. [CrossRef] [PubMed]

(C) 2016 by the authors; licensee MDPI, Basel, Switzerland. This article is an open access article distributed under the terms and conditions of the Creative Commons Attribution (CC-BY) license (http:/ / creativecommons.org/licenses/by/4.0/). 